Karagöz, B. ve Şeref, ì. (2020) Yazma becerisiyle ilgili makaleler üzerine bir inceleme: Web of Science veri tabanında eğilimler. Ana Dili Eğitimi Dergisi, 8(1), 67-86.

\begin{tabular}{c}
$\begin{array}{c}\text { Ana Dili Eğitimi Dergisi } \\
\text { Journal of Mother Tongue Education } \\
\text { www.anadiliegitimi.com }\end{array}$ \\
$\begin{array}{c}\text { Geliş/Received: } 12.09 .2019 \text { Kabul/Accepted:06.11.2019 } \\
\text { Araştırma Makalesi / Research Paper }\end{array}$ \\
\hline
\end{tabular}

\title{
Yazma Becerisiyle İlgili Makaleler Üzerine Bir İnceleme: Web of Science Veri Tabanında Eğilimler
}

\author{
Beytullah KARAGÖZ** \\ izzet ŞEREF ${ }^{* * *}$
}

\begin{abstract}
Öz
Temel dil becerilerinden biri de yazmadır. Yazma, bilişsel ve psikomotor becerilerin işe koşulduğu bir anlatma etkinliğidir. Bu çalışmada Thomson Reuters Web Of Science (WoS) veri tabanında dizinlenen yazma becerisiyle ilgili makaleleri incelemek ve mevcut eğilimler hakkında belirlemeler yapmak amaçlanmıştır. Bu kapsamda WoS veri tabanında dizinlenen 5,779 akademik makale analiz edilmiştir. Çalışma, betimsel modeldedir. Veri analiz tekniği olarak bibliyometri kullanılmıştır. Bu doğrultuda alanyazın; yayın ve etki büyüklüğü, coğrafi dağılım, güncel araştırma konuları, referans yazar, dergi ve yayınlar bakımından değerlendirilmiştir. Bibliyometrik görselleştirmeler VOSviewer (Version 1.6.9) analitik aracı kullanılarak gerçekleştirilmiştir. Çalışmada ulaşılan sonuçlara göre, en üretken ülke 2695 makale ile Amerika Birleşik Devletleri'dir. Alanyazına Türkiye'den de önemli katkılar sağlandığı görülmüştür. Steve Graham, alanyazında öne çıkan çekirdek araştırmacılardan biridir.
\end{abstract}

Anahtar Kelimeler: Türkçe eğitimi, Yazma, Web of Science, VOSviewer.

\begin{abstract}
A Review of Articles on the Writing Skill: Trends in the Web of Science Database Abstract

One of the basic language skills is writing. Writing is an expression activity in which cognitive and psychomotor skills are employed. The aim of this study is to examine the articles on the writing skill published in the journals indexed in the Thomson Reuters Web of Science (WoS) database in order to determine the existing trends. To that end 5,779 academic articles indexed in the WoS database were analyzed. The study is descriptive. Bibliometrics was used as the data analysis method. The available literature was examined in terms of publication and impact size, geographical distribution, current research topics, reference authors, journals and publications. Bibliometric visualizations were realized using the VOSviewer (Version 1.6.9) analytical tool. According to the results of the study, the most productive country was the United States with 2695 articles. Turkey made significant contributions to the literature as well. Steve Graham was identified as a leading researcher in the literature.
\end{abstract}

Keywords: Teaching Turkish, Writing, Web of Science, VOSviewer.

\section{Giriş}

Ana dili eğitimi ve öğretimi süreci dört temel dil becerisine dayalıdır. Bu dil becerilerinden biri de yazmadır. Yazma, anlatma becerileri arasında yer alır. Yazma eyleminin "Duygu ve düşüncelerin ifade aracı" (Arıcı ve Ungan, 2008); "Düşüncelerimizi ifade edebilmek için gerekli sembol ve işaretleri motorsal olarak üretebilmek" (Akyol, 2011); "Temel dil becerilerinden biri" (Epçaçan, 2013); "Herhangi bir konuda duygu, hayal ya da özgün fikirleri belli bir düzen ve bütünlük içinde yazıya geçirme işi" (Göçer, 2010); "Duygu, düşünce, istek ve olayların belli kuralarla uygun olarak birtakım

\footnotetext{
${ }^{* *}$ Doç.Dr., Tokat Gaziosmanpaşa Üniversitesi, Eğitim Fakültesi, Türkçe ve Sosyal Bilimler Eğitimi Bölümü, Tokat, E-posta, beytullah.karagoz@gop.edu.tr ORCID: 0000-0003-2966-8226

*** Dr. Öğr. Üyesi, Tokat Gaziosmanpaşa Üniversitesi, Eğitim Fakültesi, Türkçe ve Sosyal Bilimler Eğitimi Bölümü, Tokat, E-posta, izzet.seref@gop.edu.tr ORCID: 0000-0002-2379-1373
} 
sembollerle anlatılması" (Güneş, 2014); "Duygu, düşünce ve deneyimleri başkalarıyla paylaşmanın temel aracı" (Karatay, 2011); "Konuşma dili sınırları içerisinde rafine edilmiş sesin, görsel nitelikli iz düşümleri" (Onan, 2006); "Bireylerin kendilerini ifade etmeleri için kullanılan bir yol" (Özdemir ve Erdem, 2011); "Akademik eğitimin öğrenme çıktısı" (Turan, Sevim ve Tunagür, 2018); "Günlük hayatın bir pratiği" (Yazıcı, 2006) biçiminde farklı tanımları bulunmaktadır. Bu tanımlardan hareketle yazma, "Etkinlik çevresi, yazarın uzun süreli belleği ve yazma sürecini" (Ülper ve Uzun, 2009: 652) içeren çok boyutlu bir beceri alanıdır.

Yazma, taşıdığı olanaklarla insan yaşamında önemli bir dilsel beceridir. Bu yönüyle düşünmeyi teşvik eder, öğrencileri fikirlerini yoğunlaştırmaya ve düzenlemeye yöneltir ve onların özetleme, analiz etme ve eleştirme yeteneklerini geliştirir (Rao, 2007). Duyma ve düşünme süreçlerini etkinleştirerek bireyin çevresi ile olan ilişkilerini geliştirmesine katkıda bulunur. Bu yanıyla yazma "Düşünme, anlama, sıralama, sınıflama, sorgulama, ilişki kurma, analiz sentez yapma ve değerlendirme gibi zihinsel becerilerin geliştirilmesinde önemli bir işleve sahiptir" (MEB, 2018: 10). Aynı zamanda bilişsel süreçlere dayalı olarak üretilen bu beceri alanı, kuşaklararası etkileşimi sağlayarak belleği kalıcı hâle getirir. Bu bakımdan tarihsel ve kültürel mirasın gelecek nesillere aktarımına ortam hazırlar.

\section{ilgili Çalışmalar}

Yazma, Türkçe eğitimi akademik alanyazınında temel araştırma konularından biridir. Bu kapsamda alanda üretilmiş makale ve lisansüstü tez çalışmalarını ele alan araştırmalar mevcuttur. Alanyazında yazma becerisiyle ilgili çalışmaları inceleyen araştırmaların karşılaştırmalı listesi Tablo 1 'de verilmektedir.

Tablo 1.

Yazma becerisiyle ilgili çalışmaları inceleyen araştırmaların karşılaştırmalı listesi

\begin{tabular}{|c|c|c|c|c|c|c|}
\hline & Bu çalışma & $\begin{array}{l}\text { Elbir ve } \\
\text { Yıldız }\end{array}$ & $\begin{array}{c}\text { Coşkun, } \\
\text { Balcı ve } \\
\text { Özçakmak }\end{array}$ & $\begin{array}{l}\text { Tok ve } \\
\text { Potur }\end{array}$ & Göksu & Uyar \\
\hline YII & & 2012 & 2013 & 2015 & 2016 & 2016 \\
\hline $\begin{array}{c}\text { Makale } \\
\text { sayıları \& } \\
\text { atıf sayıları }\end{array}$ & $\checkmark$ & - & - & $\checkmark$ & $\checkmark$ & - \\
\hline $\begin{array}{c}\text { Etkin } \\
\text { ülke/bölge }\end{array}$ & $\checkmark$ & - & - & - & & - \\
\hline Veri tabanı & $\checkmark$ & $\checkmark$ & $\checkmark$ & $\checkmark$ & $\checkmark$ & $\checkmark$ \\
\hline $\begin{array}{c}\text { Etkin } \\
\text { makale }\end{array}$ & $\checkmark$ & - & - & - & - & - \\
\hline $\begin{array}{l}\text { Anahtar } \\
\text { kelime } \\
\text { analizi }\end{array}$ & $\checkmark$ & - & - & - & - & - \\
\hline $\begin{array}{l}\text { Kaynak } \\
\text { ortak atıf } \\
\text { ağ analizi }\end{array}$ & $\checkmark$ & - & - & - & - & - \\
\hline $\begin{array}{c}\text { Yazar ortak } \\
\text { atıf ağ } \\
\text { analizi }\end{array}$ & $\checkmark$ & - & - & - & - & - \\
\hline $\begin{array}{c}\text { Dergi ortak } \\
\text { atıf ağ } \\
\text { analizi }\end{array}$ & $\checkmark$ & - & - & - & - & - \\
\hline
\end{tabular}


Elbir ve Yıldız (2012), YÖK Ulusal Tez Merkezi veri tabanında kayıtlı yazma becerisi ile ilgili ilköğretim düzeyi lisans sonrası tezlerini incelemişlerdir. Coşkun, Balcı ve Özçakmak (2013), 19812010 döneminde Türkiye adresli yazma eğitimi lisansüstü çalışmalarındaki eğilimleri belirlemişlerdir. Tok ve Potur (2015) Türkiye'de 2010-2014 yıllarında yayımlanan yazma becerisi araştırmalarındaki (tez, makale) eğilimleri tespit etmişlerdir. Göksu (2016), ilköğretim döneminde yazma becerisine yönelik akademik makale ve tezleri incelemiştir. Uyar (2016), 1991-2016 döneminde yazma becerisini geliştirme üzerine yapılmış bilimsel çalışmaları irdelemiştir. Bu çalışmalarda Türkiye'de yazma becerisi ve yazma eğitimi üzerine yapılmış bilimsel makaleler ve lisans sonrası çalışmalar içerikleri bakımından hedef kitle, diğer dil becerileri ile ilişkiler, düzey (Yüksek lisans-Doktora), araştırma yöntemi gibi farklı değişkenler doğrultusunda ele alınmıştır. Belirtilen araştırmalarda veri analizi yöntemi olarak doküman analizi ve içerik analizi yönteminden yararlanıımıştır. Ayrıca çalışmalarda veri kaynağı olarak Ulakbim TR Dizin, Google Akademik (GS) ve YÖK Ulusal Tez Merkezi tercih edilmiştir. Bu bağlamda yazma alanyazınında bibliyometrik analize ve uluslararası bilimsel veri tabanlarına (Web of Science) dayalı bir çalışma olmadığı ve elde edilen sonuçlar alanyazına ilişkin "büyük resim" sunamadığı için, çalışmaya gereksinim duyulmuştur.

Çalışma Türkçe eğitimi akademik alanı için yol haritası oluşturulması bakımından önemlidir. Buna göre çalışmada bulguların haritalandırılması yazma eğitimi alanyazınına ilişkin bilimsel düzeyde veriler elde edilmesini mümkün kılmaktadır. Bu açıdan alanyazındaki temel araştırmacı, dergi, makale ve dokümanların saptanması alandaki araştırmacılar için bir bilgi kılavuzu niteliği taşımaktadır. Çalışmanın Türkçe eğitimi araştırmacılarının yazma becerisi ile ilgili uluslararası akademik gündemden ve güncel bilimsel eğilimlerden haberdar olmalarına olanak sağlayacağı düşünülmektedir. Böylelikle dünyadaki mevcut akademik durum/tartışmaları keşfetmek suretiyle evrensel düzeyde bilim üretme olanağı elde edilebilir. Bu yaklaşım Türkçe eğitimi bilim alanının uluslararası bilgi birikimi ile bağlantısını güçlendirebilir. Dolayısıyla çalışma yazma becerisi alanında WoS veri tabanında dizinlenen makaleleri sistematik bakış açısıyla analiz etmesi ve Türkçe eğitimi akademik alanındaki araştırmacılara uluslararası bilim çevreleri tarafından üretilen bilgi birikiminden yararlanma olanağı sağlayacağı için önemli görülmektedir. Bu çalışmada yazma becerisine ilişkin WoS çekirdek koleksiyonunda listelenen makaleleri bibliyometrik analiz yöntemiyle incelemek ve Türkçe eğitimi akademik alanına yeni bir araştırma çerçevesi sunmak amaçlanmıştır. Bu amaç doğrultusunda çalışmada "WoS'ta listelenen yazma becerisine ilişkin makalelerin bibliyometrik görünümleri nasıldır?" sorusuna yanıt aranmıştır.

\section{Araştırmanın Modeli}

\section{Yöntem}

Nicel araştırma geleneğine dayalı bu araştırma, betimsel modeldedir. Betimsel yöntemin kullanıldığı "Araştırmalarda durum nedir?, neredeyiz?, ne yapmak istiyoruz?, nereye, hangi yöne gitmeliyiz?, oraya nasıl gideriz? gibi sorulara, mevcut zaman kesiti içinde olduğu düşünülen verilere dayanılarak cevap bulunmak istenir" (Kaptan, 1995: 59). Araştırmada yazma becerisiyle ilgili makaleleri bibliyometrik değişkenler açısından ele almak ve uluslararası bilimsel veri tabanları üzerinden alanyazındaki eğilimleri tespit etmek suretiyle sistematik bir durum değerlendirmesi yapılmak amaçlandığı için çalışma betimsel araştırma olarak desenlenmiştir.

\section{Verilerin Toplanması}

Bilim haritalamaya dayalı alanyazın değerlendirme çalışmalarında bibliyografik veri tabanı son derece önemlidir. Çünkü veri tabanları sahip oldukları özellikler ile araştırmacılara çeşitli olanaklar sunmaktadır. Bibliyografik araştırmalarda yaygın olarak kullanılan veri tabanları bulunmaktadır. Bunlardan bazıları Scopus, Web of Science (WoS) Google Akademik (GS), Microsoft Academic (MA) ve Education Resources Information Center (ERIC) veri tabanlarıdır. Scopus ve Web of Science, aboneli veri tabanları olup ticari şirketler tarafından yönetilir. Google Akademik, Microsoft Academic ve ERIC veri tabanları ise ücretsiz açık erişimli veri kaynaklarıdır. Bu çalışmada Web of Science (WoS), veri tabanı kullanılmıştır. WoS SCI-Expanded (Science Citation Index-Expanded), SSCl (Social Science Citation Index) ve $\mathrm{A} \& \mathrm{HCl}$ (Arts and Humanities Citation Index) atıf dizinlerini kapsamaktadır. Bu 
yönüyle, farklı konu kategorilerindeki araştırmalar için "big data" (büyük veri) oluşturmaktadır. Araştırmacılar büyük veri analizinden elde ettikleri veriler ile alanyazındaki bilimsel etkinliği izleyerek bilim alanlarındaki genel durumu, eğilim ve gelişmeleri gözlemleme olanağı bulmaktadır. Bu nedenle çalışmada belirtilen veri tabanından yararlanılmıştır.

Yazma becerisi ile ilgili hakemli makalelere ulaşmak için WoS veri tabanında 05.08.2019 tarihinde çevrim içi sorgulama yapılmıştır. Bu taramada sorgu için aşağıdaki anahtar sözcük grubu kullanılarak veri seti hazırlanmıştır:

$T I=(" w r i t i n g " ~ O R$ "writing education" OR "writing skills" OR "writing ability" OR "writing teaching" $O R$ "early reading and writing" OR "first grade literacy readiness" OR "writing self-efficacy" $O R$ "digital writing" $O R$ "writing difficulties" $O R$ "early literacy skills" $O R$ "cursive writing teaching skills" $O R$ "manuscript handwriting" OR "first reading and writing instruction" OR "writing errors)

Timespan=All years. Indexes=SCI-EXPANDED, SSCI, A\&HCI, CPCI-S, CPCI-SSH, BKCI-S, BKCI-SSH, $E S C l$

Yapılan sorguda WoS çekirdek koleksiyonunda yazma alanyazını ile ilgili 63,677 yayına erişilmiştir. Doküman türlerine göre en çok makale $(30,000,47.12 \%)$ türünde belge üretilmiştir. Daha sonra sırasıyla kitap değerlendirme $(19.934,31.30 \%)$, bildiri $(5.545,8.70 \%)$ ve kitap bölümü $(5,010$, 7.86\%) gelmektedir. Alanyazında 6 farklı belge türünde yayın üretildiği görülmüştür. WoS kategorilerinde yazma alanyazınındaki yayınların 68 farklı kategoride dağııım gösterdiği belirlenmiştir. Bu bağlamda tarama sorgusu WoS çekirdek koleksiyonunda eğitim ve eğitimsel araştırmalar (Education \& Educational Research) kategorisinde gerçekleştirilmiştir. Buna göre veri seti makale (article) belge türü ile sınırlandırılarak toplamda 5.779 makaleye ulaşılmıştır. Elde edilen bu kayıtlar çalışmanın veri setini oluşturmaktadır.

\section{Verilerin Analizi}

Araştırmada veri analizi yöntemi olarak bibliyometriden yararlanılmıştır. Çalışmada bibliyometrik analiz, yedi kategori üzerinden gerçekleştirilmiştir. Bu kategoriler şunlardır: (1) Makale ve atıf sayıları, (2) Etkin ülkeler/bölgeler, (3) Alanyazına yön veren makaleler, (4) Anahtar kelime analizi, (5) Doküman (Kaynak) ortak atıf ağ analizi, (6) Dergi ortak atıf ağ analizi, (7) Yazar ortak atıf ağ analizi.

Bibliyometri yöntemi, "Yayınların belirli özelliklerinin analiz edilmesi yoluyla bilimsel iletişime ilişkin çeşitli bulguların elde edildiği bir alandır" (Al, 2012: 1). Yılmaz'a göre (2019: 44) "Bilimsel bilginin üretiminin ve bu üretimin farklı unsurlara göre dağılımının bibliyometri gibi niceliksel yöntemlerden yararlanmak suretiyle incelenmesi şüphesiz ki söz konusu bilgilerin çeşitli özelliklerinin saptanmasında bizlere kısmen kolaylık sağlar." Bu yönüyle bibliyometri çalışmaları bilimsel etkinlik ve literatür analizini mümkün kılmaktadır. Bu doğrultuda çalışmada bilim haritalama kullanılııştır. Bilim haritalama, belirli disiplinlerin, bilimsel alanların veya araştırma alanlarının kavramsal, entelektüel ve sosyal olarak nasıl yapılandırıldığını açıklayan bibliyometrik haritalar oluşturmayı amaçlamaktadır (Cobo, López-Herrera, Herrera-Viedma ve Herrera, 2011). Bu amaçla analitik araçlar aracılığıyla oluşturulan bibliyometrik haritalar alandaki var olan ve ortaya çıkan konu alanlarını tespit etmek için kullanılabilir. Ayrıca, yazar ve kurumsal özelliklere dayanarak çeşitli düşünce alanlarının nasıl ortaya çıktığını gösteren araştırma kümelerinin ve araştırmacıların belirlenmesine yardımcı olabilir (Fahimnia, Sarkis ve Davarzani, 2015). Bilim haritalamanın değeri, bir veri tabanı oluşturmak için uygun olan ögeleri (örneğin, zaman, coğrafi kaynaklar, araştırmacılar, konular, kurumlar) oluşturmak için çok sayıda çalışmayı analiz etme kabiliyetinde yatmaktadır (Kovačević ve Hallinger, 2019).

Bibliyometrik yazılım araçları, bibliyometrik verilerin görselleştirilmesinde önem arz etmektedir. Verileri haritalandırma sürecinde VOSviewer analitik aracının version 1.6.9 sürümünden yararlanılmıştır. VOSviewer, VOS haritalama tekniğine kolay erişim sağlayan bir grafik kullanıcı arayüzü sunar. Yazılım ayrıca, bibliyometrik haritaların görselleştirilmesini ve etkileşimli incelemesini kapsamlı bir şekilde destekler (Van Eck ve diğerleri, 2010). Örneğin bir konuya olan ilginin zaman içinde nasıl arttığını veya azaldığını gösteren kümelenme dinamiklerini görünür hâle getirebilir (Van Eck ve Waltman, 2017). 
WoS atıf dizininde listelenen makalelerin dünya ölçeğinde dağılımını göstermek amacıyla GunnMap açık kaynak yazılımı kullanılmıştır. Bu yazıııma ücretsiz olarak (http://lert.co.nz/map/) adresinden erişilebilmektedir.

Çalışmanın raporlaştırılması sürecinde araştırmacılar metin, tablo ve görsel (bibliyometrik harita) uyumunu gözden geçirerek araştırmanın iç geçerliğini sağlamaya çalışmışlardır. Dış geçerliği artırmak için araştırma süreçleri ve ulaşılan verileri ayrıntılı biçimde betimlemişlerdir. Araştırmacılar, raporunun yazımından sonra çalışmayı uzman teyidi için yazma eğitimi çalışan bir Türkçe eğitimi alan uzmanı ile bir illk okuma yazma eğitimcisine göndermiştir. Uzmanlardan gelen öneriler doğrultusunda araştırma raporu üzerinde dil ve anlatıma yönelik düzenlemeler gerçekleştirilmiştir.

\section{Bulgular}

Bu çalışmada, WoS çekirdek dizinlerinde yayımlanan makaleler bibliyometri kullanılarak değerlendirilmiş ve VOSviewer analitik aracı yardımı ile görselleştirilmiştir. Çalışmada elde edilen bulgular aşağıda bölümler hâlinde sunulmuştur.

\section{Yayın Sayıları/Atıf Sayıları}

Yazma alanyazınındaki akademik makalelerin sayısal dağııımı ve atıf sayısı aşă̆ıda verilmektedir (Grafik 1).

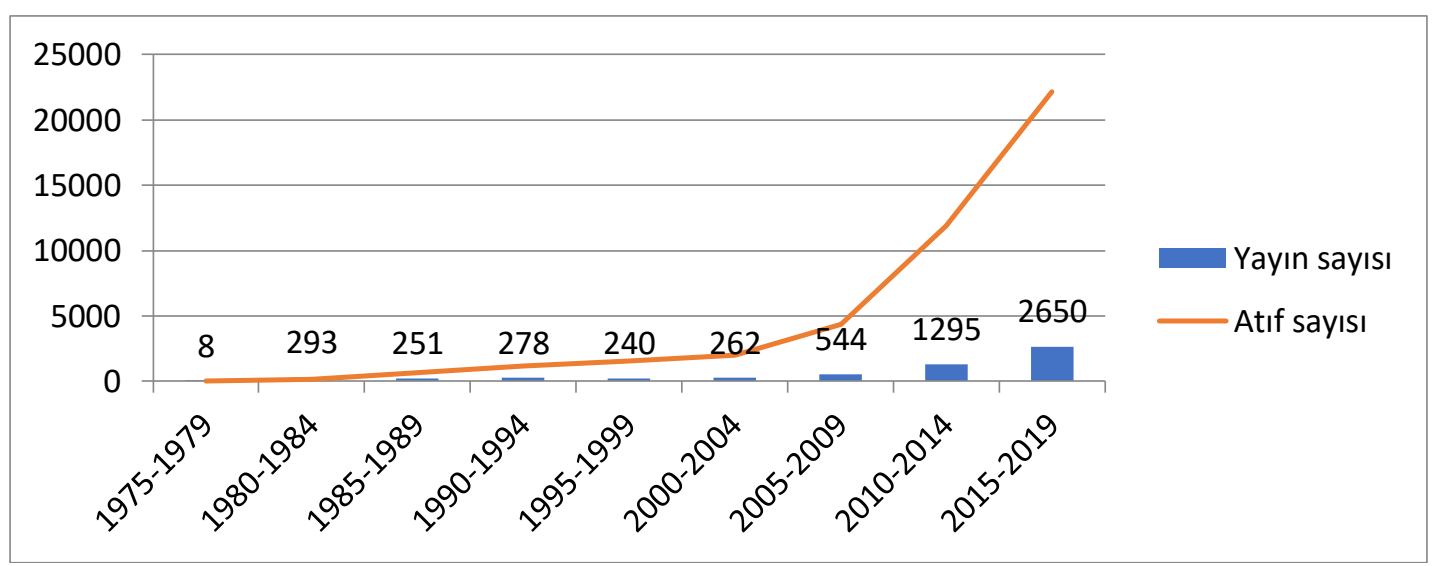

Grafik 1. WoS yayın ve atıf sayılarının yıllara göre sayısal dağılımı (05.08.2019)

Grafik 1'de WoS verilerine göre yazma alanyazınındaki makalelerin yıl bazında dağııımı ve atıf sayıları gösterilmiştir. Yazma becerisiyle ilgili üretilen makale sayısı toplam 5.779 'dur. En çok makale 2015-2019 yılları arasında yayımlanmıştır (2650, 45.85\%). Daha sonra sırasıyla 2010-2014 yılları (1295, 22.40\%) ve 2005-2009 yılları (544, 9.41\%) takip etmektedir. Makale sayıları 2005 yılına kadar belirli bir düzeyde seyir izlerken, 2005-2009 döneminden sonra kademeli olarak artış göstermiştir. Alanyazındaki makalelerin yayın sayısından daha çok sayıda atıf aldığı dikkat çekmektedir.

\section{Etkin Ülkeler/Bölgeler}

WoS atıf dizininde yazma becerisi ile ilgili makalelerin ülkelere göre coğrafi dağııımı aşağıda gösterilmiştir. 


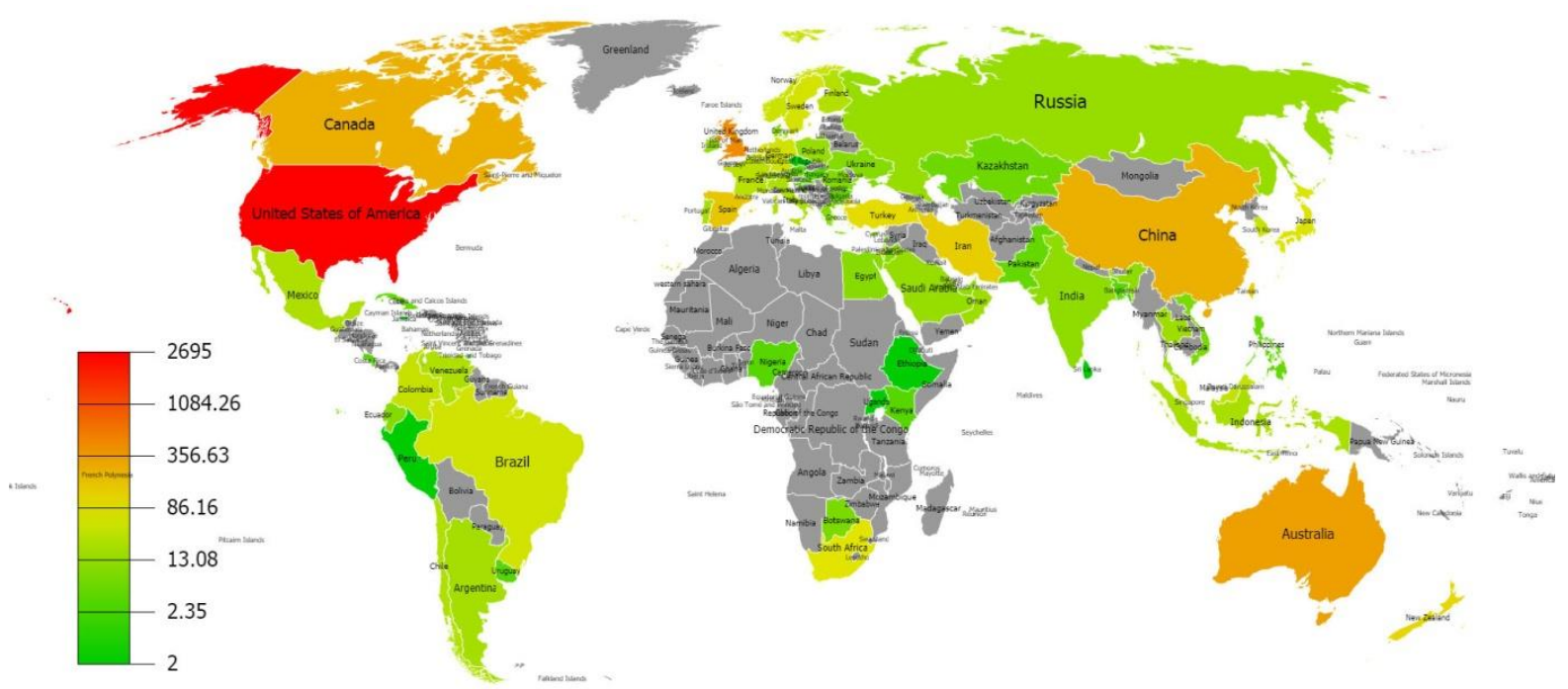

Grafik 2. Yayın sayılarının ülkelere göre dağılımı (05.08.2019).

Grafik 2, alanyazına en çok katkıda bulunan ülkelere ilişkin veriler sunmaktadır. GunnMap (http://lert.co.nz/map/) yazılımı kullanılarak ülke ve bölge bazında makale yoğunlukları dünya haritası üzerinde görselleştirilmiştir. Veriler Clarivate Analytics tarafından üretilen bilgilerden derlenmiştir. Buna göre yayın sayıları yeşil renkten kırmızı renge doğru yoğunluk göstermektedir. Toplam yayın sayısı bakımından en yoğun ülke Amerika Birleşik Devletleridir $(n=2695)$. Daha sonra sırasıyla İngiltere $(n=500)$, Avustralya $(n=348)$, Kanada $(n=264)$ ve Çin $(n=259)$ gelmektedir. Türkiye alana önemli katkılarda bulunan ilk on ülkeden biridir $(n=106)$. Bununla birlikte 2 ve üzeri yayınla alana katkı sağlayan ülkelerden 29'u Avrupa'dan; 25'i Asya'dan; 12'si Güney Amerika'dan; 6'sı Afrika'dan; 3'ü Kuzey Amerika'dan; 2'si Okyanusya'dandır.

\section{Alanyazında En Sık Atıf Alan Makaleler}

Alanyazında en sık atıf alan makalelerin saptanması son derece önemlidir. Çünkü bu araştırmalar, alandaki bilgi birikimine kaynaklık eder. Bu yanıyla alandaki bilimsel arka plan anılan araştırmalar üzerinden biçimlenmektedir. Yazma alanyazınında bilim iletişiminin artmasına katkıda bulunan makaleler aşağıda verilmektedir (Tablo 2).

Tablo 2.

En çok atıf alan ilk 20 makale

\begin{tabular}{cccccc}
\hline Sira & Yayın Adı & Yazar/lar & $\begin{array}{c}\text { Yayın } \\
\text { Yılı }\end{array}$ & $\begin{array}{c}\text { WoS } \\
\text { Atıf } \\
\text { Sayıs }{ }^{1}\end{array}$ & Dergi \\
\hline $1 \quad \begin{array}{c}\text { Student writing in higher } \\
\text { education: An academic literacies } \\
\text { approach }\end{array}$ & $\begin{array}{c}\text { Lea, M. R., ve Street, } \\
\text { B. V. }\end{array}$ & 1998 & 651 & $\begin{array}{c}\text { Studies in } \\
\text { Higher } \\
\text { Education }\end{array}$ \\
\hline 2 & $\begin{array}{c}\text { Impact of self-regulatory } \\
\text { influences on writing course } \\
\text { attainment }\end{array}$ & $\begin{array}{c}\text { Zimmerman, B. J., ve } \\
\text { Bandura, A. }\end{array}$ & 1994 & 371 & $\begin{array}{c}\text { American } \\
\text { Educational } \\
\text { Research } \\
\text { Journal }\end{array}$ \\
\hline 3 & $\begin{array}{c}\text { The effects of school-based } \\
\text { writing-to-learn interventions on } \\
\text { academic achievement: A meta- }\end{array}$ & $\begin{array}{c}\text { Bangert-Drowns, R. L., } \\
\text { Hurley, M. M., ve } \\
\text { Wilkinson, B. }\end{array}$ & 2004 & 262 & $\begin{array}{c}\text { Review of } \\
\text { Educational } \\
\text { Research }\end{array}$ \\
\hline
\end{tabular}

${ }^{1}$ WoS atıf sayıları, WoS atıf dizininde listelenen diğer yayınların atıflarına göre belirlenmektedir (05.08.2019). 


\begin{tabular}{|c|c|c|c|c|c|}
\hline & analysis & & & & \\
\hline 4 & $\begin{array}{l}\text { Codemeshing in academic writing: } \\
\text { Identifying teachable strategies of } \\
\text { translanguaging }\end{array}$ & Canagarajah, S & 2011 & 231 & $\begin{array}{c}\text { The Modern } \\
\text { Language } \\
\text { Journal }\end{array}$ \\
\hline 5 & $\begin{array}{l}\text { L2 literacy and the design of the } \\
\text { self: A case study of a teenager } \\
\text { writing on the Internet }\end{array}$ & Lam, W. S. E. & 2000 & 216 & $\begin{array}{c}\text { TESOL } \\
\text { Quarterly }\end{array}$ \\
\hline 6 & $\begin{array}{l}\text { Toward an understanding of the } \\
\text { distinct nature of L2 writing: The } \\
\text { ESL research and its implications }\end{array}$ & Silva, $\mathrm{T}$ & 1993 & 216 & $\begin{array}{c}\text { TESOL } \\
\text { Quarterly }\end{array}$ \\
\hline 7 & $\begin{array}{c}\text { The role of self-regulation and } \\
\text { transcription skills in writing and } \\
\text { writing development }\end{array}$ & $\begin{array}{l}\text { Graham, S., ve R. } \\
\text { Harris, K. }\end{array}$ & 2000 & 191 & $\begin{array}{l}\text { Educational } \\
\text { Psychologist }\end{array}$ \\
\hline 8 & $\begin{array}{l}\text { Lower-level developmental skills in } \\
\text { beginning writing }\end{array}$ & $\begin{array}{l}\text { Berninger, V., Yates, } \\
\text { C., Cartwright, A., } \\
\text { Rutberg, J., Remy, E., } \\
\text { ve Abbott, R. }\end{array}$ & 1992 & 189 & $\begin{array}{l}\text { Reading and } \\
\text { Writing, }\end{array}$ \\
\hline 9 & $\begin{array}{c}\text { Bilingualism, biliteracy, and } \\
\text { learning to read: Interactions } \\
\text { among languages and writing } \\
\text { systems }\end{array}$ & $\begin{array}{l}\text { Bialystok, E., Luk, G., } \\
\text { ve Kwan, E. }\end{array}$ & 2005 & 188 & $\begin{array}{l}\text { Scientific } \\
\text { Studies of } \\
\text { Reading }\end{array}$ \\
\hline 10 & $\begin{array}{l}\text { Improving the writing, knowledge, } \\
\text { and motivation of struggling young } \\
\text { writers: Effects of self-regulated } \\
\text { strategy development with and } \\
\text { without peer support }\end{array}$ & $\begin{array}{c}\text { Harris, K. R., Graham, } \\
\text { S., ve Mason, L. H. }\end{array}$ & 2006 & 185 & $\begin{array}{l}\text { American } \\
\text { Educational } \\
\text { Research } \\
\text { Journal }\end{array}$ \\
\hline 11 & $\begin{array}{l}\text { Scaffolded writing and rewriting in } \\
\text { the discipline: A web-based } \\
\text { reciprocal peer review system }\end{array}$ & $\begin{array}{c}\text { Cho, K., ve Schunn, C. } \\
\text { D. }\end{array}$ & 2007 & 176 & $\begin{array}{l}\text { Computers \& } \\
\text { Education }\end{array}$ \\
\hline 12 & $\begin{array}{l}\text { Making strategies and self-talk } \\
\text { visible: Writing instruction in } \\
\text { regular and special education } \\
\text { classrooms }\end{array}$ & $\begin{array}{l}\text { Englert, C. S., Raphael, } \\
\text { T. E., Anderson } \\
\text { Helene M. Anthony, L. } \\
\text { M., ve Stevens, D. D. }\end{array}$ & 1991 & 175 & $\begin{array}{c}\text { American } \\
\text { Educational } \\
\text { Research } \\
\text { Journal }\end{array}$ \\
\hline 13 & $\begin{array}{c}\text { Reading and writing relations and } \\
\text { their development }\end{array}$ & $\begin{array}{l}\text { Fitzgerald, J., ve } \\
\text { Shanahan, T. }\end{array}$ & 2000 & 172 & $\begin{array}{l}\text { Educational } \\
\text { Psychologist }\end{array}$ \\
\hline 14 & Responding to student writing & Zamel, V. & 1985 & 168 & $\begin{array}{c}\text { TESOL } \\
\text { Quarterly }\end{array}$ \\
\hline 15 & $\begin{array}{c}\text { Salience of feedback on error and } \\
\text { its effect on EFL writing quality }\end{array}$ & $\begin{array}{l}\text { Robb, T., Ross, S., ve } \\
\text { Shortreed, I. }\end{array}$ & 1986 & 166 & $\begin{array}{c}\text { TESOL } \\
\text { Quarterly }\end{array}$ \\
\hline 16 & $\begin{array}{c}\text { Knowledge, processing, and } \\
\text { working memory: Implications for } \\
\text { a theory of writing. }\end{array}$ & McCutchen, D. & 2000 & 163 & $\begin{array}{l}\text { Educational } \\
\text { Psychologist }\end{array}$ \\
\hline 17 & $\begin{array}{l}\text { Writing expertise and second- } \\
\text { language proficiency. }\end{array}$ & Cumming, A. & 1989 & 160 & $\begin{array}{l}\text { Language } \\
\text { Learning }\end{array}$ \\
\hline 18 & $\begin{array}{l}\text { Epistemic levels in argument: An } \\
\text { analysis of university } \\
\text { oceanography students' use of } \\
\text { evidence in writing. }\end{array}$ & $\begin{array}{c}\text { Kelly, G. J., ve Takao, } \\
\text { A. }\end{array}$ & 2002 & 153 & $\begin{array}{l}\text { Science } \\
\text { Education }\end{array}$ \\
\hline 19 & $\begin{array}{l}\text { Language anxiety: Differentiating } \\
\text { writing and speaking components }\end{array}$ & $\begin{array}{l}\text { Cheng, Y. S., Horwitz, } \\
\text { E. K., ve Schallert, D. } \\
\text { L. }\end{array}$ & 1999 & 151 & $\begin{array}{l}\text { Language } \\
\text { Learning }\end{array}$ \\
\hline
\end{tabular}




\begin{tabular}{|c|c|c|c|c|c|}
\hline 20 & $\begin{array}{c}\text { Using the science writing heuristic } \\
\text { as a tool for learning from } \\
\text { laboratory investigations in } \\
\text { secondary science }\end{array}$ & $\begin{array}{l}\text { Keys, C. W., Hand, B., } \\
\text { Prain, V., ve Collins, S. }\end{array}$ & 1999 & 140 & $\begin{array}{l}\text { Journal of } \\
\text { Research in } \\
\text { Science } \\
\text { Teaching }\end{array}$ \\
\hline
\end{tabular}

Alanyazında 140 ve üzeri atıf alan araştırmalar Tablo 2'de gösterilmiştir. Buna göre en çok atıf yapılan makale, Lea, M. R., ve Street, B. V. tarafından yayımlanan "Student writing in higher education: An academic literacies approach" başlıklı akademik yayındır. Makale WoS çekirdek koleksiyonunda 1998'den bugüne 651 atıf almıştır. Makalede yükseköğretim öğrencilerinin yazma durumları konu edilmektedir. Çalışma geleneksel model ve yaklaşımlar yerine yeni bir yaklaşım olarak 'akademik okuryazarlık' modelini önermektedir. En sık atıf yapılan ikinci makale, 1994 yılında Zimmerman, B. J., ve Bandura, A. tarafından yayımlanan "Impact of self-regulatory influences on writing course attainment" başıkıı yayındır. Çalışma, akademik öz yeterlik inancının akademik hedefler ve yazma dersi başarısında etkili olduğu ortaya koymuştur. Çalışma toplamda 371 atıf almıştır. TESOL Quarterly (n=4; IF: 2, 71; QC: 1) dergisi daha fazla sayıda çekirdek makaleye ev sahipliği yaparak alandaki dergilerden ayrışmaktadır. Bu yanıyla derginin alanyazındaki bilimsel gelişime katkıda bulunduğunu söylemek mümkündür.

\section{Anahtar Kelime Analizi}

"Bilimsel araştırmalarda yazarın kullandığı anahtar kelimeler çalışmanın yapı ve içeriğini anlamak açısından belirleyicidir" (Karagöz ve Şeref, 2019b: 236). Başka bir deyişle, bilimsel bir makalenin alanyazındaki yerini belirleyen koddur. Araştırmacılar, bilimsel makalelerini alanyazına tanımlarken çalışmalarını özetleyen anahtar kelimeler oluştururlar. Bu kapsamda aynı makalede yakın iki anahtar kelime bulunması, değindiği konular arasında bir ilişki olduğunu gösterir (Cambrosio ve diğerleri, 1993). Başka bir değerlendirmeye göre yazar anahtar kelime analizi araştırmacılara alandaki araştırma eğilimleri hakkında bilgi sunabilir (Garfield, 1990). Yazarlar tarafından çalışmalara atanan anahtar kelimelerin hangi noktalarda yoğunlaştığı belirlenerek ilgili alanyazın tematik olarak değerlendirilebilir. Bu analizde WoS'ta listelenen yazma becerisi ile ilgili makalelerin bilimsel yönelimlerini anlayabilmek amacıyla yazar anahtar kelimelerine dayalı olarak birlikte bulunma (cooccurance) analizi gerçekleştirilmiştir. Bu analiz biriminde incelenen makalelerde yer alan çekirdek anahtar kelimeler ve bu terimlerle birlikte en sık görülen diğer terimlerin yoğunluğu sistematik olarak belirlenir (Buzydlowski, White ve Lin, 2002: 134). Yazma becerisi ile ilgili makalelere atanan 6677 anahtar kelimeden " 5 " eşik değerini karşılayan 415 kelime çiftinin kavramsal yapısı aşağıda haritalandırılmıştır (Şekil 1). 


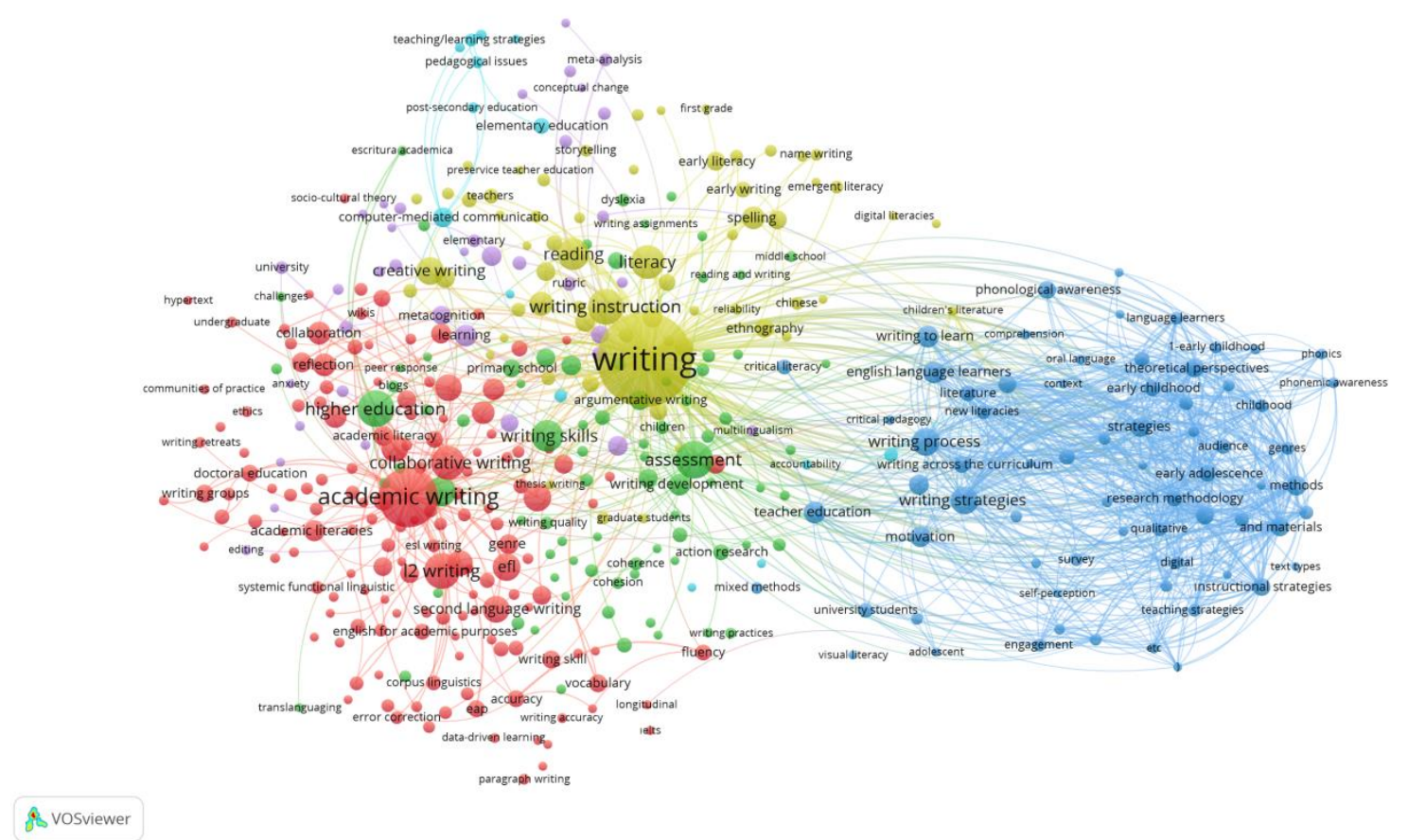

Şekil 1. Anahtar kelime ağ haritası

Şekil 1'de yazma becerisi ile ilgili anahtar kelimelerin 6 ana küme oluşturduğu görülmektedir. Buna göre birinci kümenin kırmızı (Toplam Düğüm=149), ikinci kümenin yeşil ( $T D=82)$, üçüncü kümenin mavi (TD=69), dördüncü kümenin sarı $(T D=63)$, beşinci kümenin mor $(T D=37)$, altıncı kümenin ise turkuaz (TD=14) olduğu anlaşılmaktadır.

Kırmızı kümede öne çıkan terim "akademik yazma"dır [Toplam Bağlantı Gücü (TBG)=293, Bağlantılar=190]. Aynı kümede "akademik yazma"dan sonra "iş birlikli yazma", "akran geri bildirimi", "ikinci dilde yazma", "pedagoji", "akademik okuryazarlık" gibi terimler dikkat çekmektedir. Bu kümenin daha çok yazma becerisinin alt alanı olarak "akademik yazma" ile ilgili olduğu söylenebilir. Bir diğer veriye göre bu konu alanı 2016 yılından sonra araştırmacıların ilgisini çekmeye başlamıştır. Bu yönüyle akademik yazmanın alanyazında popüler bir konu olduğunu söylemek mümkündür.

Yeşil kümede yazma becerisini ölçme, değerlendirme ve geliştirme ile ilgili anahtar kelimelerin yer aldığı görülmektedir. Bu kümenin en güçlü düğümünü "değerlendirme" anahtar kelimesi oluşturmaktadır (TBG=226, Bağlantılar=76). Bu terimi "yazma becerileri", "tartışma yazımı", "yazma gelişimi", "yüksek öğretim", "geri bildirim", "müfredat" gibi anahtar kelimeler izlemektedir. Bu kümede yer alan güncel konu alanları ise müfredatta yazma becerisinin ölçme ve değerlendirmesinin nasıl yapıldığı, yazma öğretiminde ölçme ve değerlendirme, yazma becerisine yönelik öğrenci tutumlarının saptanması, öğrencilerin yazma kaygılarının belirlenmesi, yazma becerisinin ölçme ve değerlendirmesinde planlama ile yazım başarısı gibi konulardır.

Mavi küme, yazma becerisinin alt alanı olan yazma stratejileri, yazma sürecinde uygulanan öğretim teknikleri ve yöntemler çerçevesinde yoğunlaşmaktadır. Bu kümede en yüksek düğüm yoğunluğuna sahip olan anahtar kelime "yazma stratejileri"dir (TBG=300, Bağlantılar=43). Bu kelime çiftini "stratejiler", "kuramsal bakış açıları", "materyal”, "metotlar", "araştırma metodolojisi", "yazma süreci", "öğretim stratejisi" anahtar kelimeleri takip etmektedir. Haritadan elde edilen bir başka veri, bu konuların yazma alanının en güncel çalışma alanları olduğunu ortaya koymaktadır. Öz bir anlatımla son yıllarda yazma alanında diğer alt alanlara göre öğretim stratejileri, yöntemleri ve teknikleri üzerinde daha çok durulduğunu belirtmek mümkündür.

Sarı küme yazma becerisi ile ilgili temel konulardan oluşmaktadır. Bu kümede en çok kullanılan ve diğer kümelerle güçlü bağlantılara sahip olan "yazma" terimi dikkat çekmektedir (TBG=1254, Bağlantılar=489). "Yazma"yı; "yazma öğretimi”, "okuma", "okuryazarlık", "yaratıcı 
yazma", "yazım" gibi terimler takip etmektedir. Bu kavramlar yazma becerisi alanyazınında sıklıkla üzerinde durulan konular hakkında bilgi vermesi bakımından önemlidir.

Mor kümede bütüncül bir görüntünün dışında gevşek bir ağ örüntüsü söz konusudur. Bu durum yazma becerisi ile ilgili mor kümede farklı konu alanlarından söz edilebileceğini göstermektedir. Bu kümede en sık düğüm yoğunluğuna sahip anahtar kelime "öğrenme"dir (TBG=26, Bağlantılar=56). "Öğrenme"den sonra "öğrenme amaçlı yazma”, "üstbiliş", "akran değerlendirme", "öz değerlendirme", "tartışma" terimleri öne çıkmaktadır. Söz konusu anahtar kelimeler, mor kümede yazma becerisinin öğrenimi ile ilgili konu alanlarının bulunduğunu göstermektedir. Açıklayıcı bir anlatımla bu kümede daha çok yazma sürecinin temel ögesi olarak öğrencinin beceriyi edinme süreci üzerinde durulmuştur. Bununla birlikte bu kümedeki konu alanlarının güncelliğini kaybettiğini belirtmek gerekir.

\section{Atıf Yapılan Kaynakların Ağ Analizi}

Akademik bir alanda bilimsel üretim yapan araştırmacılar, çalışmalarını temellendirmek amacıyla ilgili alanyazın açısından önemli olan temel kaynaklara atıfta bulunmak durumundadırlar. Bu bir zorunluluk olduğu gibi gerçekleştirilen çalışma ile alanyazın arasında bilimsel bağ kuran önemli bir iletişim kanalıdır. Bir başka ifadeyle bilimsel üretim esnasında alanyazında sıklıkla başvurulan temel kaynakların bilinmesi bilimsel çalışmaların kalitesini artırabilir.

Atıf analizi, araştırmacılara kendi alanlarında yön verici özelliğe ulaşmış kaynakların bilinmesi konusunda yardımcı olan bir analiz türüdür. Bu analizle ilgili alanyazında belirleyici rolü olan kaynak, dergi ve yazarlar belirlenebilir. Bu analizin yazarlar, yazılar, dergiler vb. arasındaki ilişkileri ve bağlantıları ölçmek ve bilimde ana akım veya en azından öncü olanı tanımlamak için etkili bir yöntem olduğu düşünülmektedir (Tsay, Xu ve Wu, 2003). Bu çalışmada yazma alanyazınında en sık birlikte atıf yapılan kaynakların belirlenmesi için VOSviewer analitik aracı ile ortak atıf analizi (co-citation) yapılmıştır. Bu analiz türü herhangi bir alanın yapısını ortaya çıkarmak amacıyla kullanılır (Chen, 1999: 402). Şekil 2'de yazma alanyazınında en sık birlikte atıf yapılan kaynakların ağ haritası sunulmaktadır. Ağ haritası, atıf yapılan toplam 117,796 kaynaktan en az "20" kez atıf alan 521 kaynakla oluşturulmuştur.

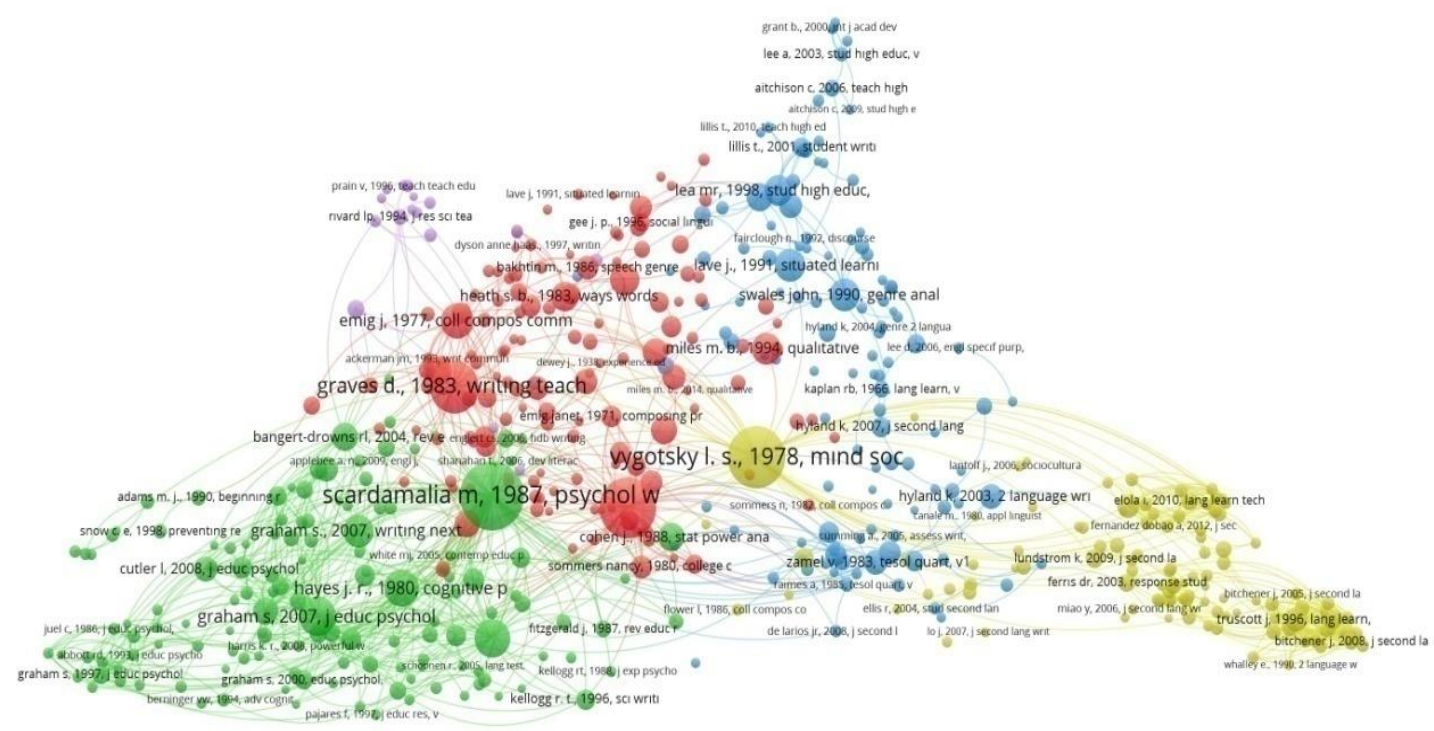

Şekil 2. Birlikte atıf yapılan kaynak ağ haritası 
Şekil 2'de yazma alanyazınında en sık birlikte atıf yapılan kaynakların 5 küme oluşturduğu görülmektedir. Bu kümelerden ilki olan kırmızı kümenin $T D=139$, yeşil kümenin $T D=138$, mavi kümenin $T D=119$, sarı kümenin $T D=109$, mor kümenin ise $T D=16$ düğümden oluştuğu gözlenmektedir. Bir başka anlatımla en sık düğüm yoğunluğuna sahip küme kırmızı küme iken, en gevşek dügüm yapısına sahip küme ise mor kümedir.

Yeşil kümede en güçlü düğüm yapısına sahip kaynak Carl Bereiter ve Marlene Scardamalia'ya tarafından kaleme alınan The Psychology of Written Composition adlı eserdir (TBG=2885, Bağlantılar=314). Bu çalışma Taylor \& Francis yayınevi üyesi ve sosyal ve beşerî bilimler alanında dünyanın önde gelen yayıncılarından biri olan Routledge Yayınları arasında yer almaktadır. Eserin ilk baskı yılı 1987'dir. Bu çalışmanın en önemli özelliği yazmayı bilişsel bir beceri olarak ele alıyor olmasıdır. Bunun yanında eser, yazmayı zihinsel süreçler ışı̆̆ında açıklayan temel kaynaklardan biri olması nedeniyle önemlidir. Yeşil kümede dikkat çeken bir başka kaynak Steve Graham ve Dolores Perin'in 2007 yılında yayımladıkları "A Meta-Analysis of Writing İnstruction for Adolescent Students" adlı makaledir. Anılan çalışma Journal of Educational Psychology dergisinin 99. sayısında yer almaktadır. Makale, yetişkin öğrencilerin yazma becerisi edinme süreçlerini konu edinen araştırmaları incelemeye dayalı olarak planlanmıştır. Yine Steve Graham ve Dolores Perin tarafından 2007 yılında yayıma hazırlanan "Writing Next: Effective Strategies to Improve Writing of Adolescents in Middle and High Schools" adlı çalışma bir bilimsel rapor niteliği taşımaktadır.

Kırmızı kümede en güçlü düğüm yoğunluğuna sahip araştırma, Linda Flower ve John Richard Hayes'e ait olan "A Cognitive Process Theory of Writing" adlı makaledir (TBG=2208, Bağlantılar=262). Bu çalışmada yazarlar yazma becerisini bilişsel bir süreç olarak değerlendirmişlerdir. Çalışmanın 1981 yılında yayımlandığı düşünüldüğünde araştırmacıların konuyu orijinal bir bakış açısıyla ele aldığını söylemek mümkündür. Bu araştırmayı Donald Graves'ın 1983 yılında yayınladığı "Writing: Teachers and Children at Work" adlı kitap izlemektedir (TBG=1351, Bağlantılar=211).

Mavi kümede, en dikkat çeken eser John M. Swales'in Genre Analysis: English in Academic and Research Settings başıklı kitabıdır (TBG=814, Bağlantılar=109). Bu çalışma akademik yazma ile ilgili hem kuramsal bilgi hem de uygulama örnekleri sunan bir eser olması yönüyle yazma alanında ilgi görmüştür. Mavi kümede düğüm yoğunluğu bakımından dikkat çeken bir başka araştırma Jean Leva ve Etienne Wenger tarafından hazırlanan Situated Learning: Legitimate Peripheral Participation adlı kitaptır (TBG=733, Bağlantılar=110). Araştırmacılar bu eserlerinde, öğrenme süreci üzerinde durmuş ve bu süreçte çoğunlukla sosyal çevrenin önemli bir etken olduğu görüşünü tartışmışlardır.

Sarı kümede en çok atıf yapılan araştırma Rus psikolog Lev S. Vygotsky'nin 1978 yılında yayımladığı Mind in Society: The Development of Higher Psychological Processes başlıklı eseridir (TBG=1874, Bağlantılar=271). Kitap "Toplumdaki Zihin: Yüksek Psikolojik Proseslerin Gelişimi” adıyla Türkçeye kazandırılmıştır. Diyalektik-materyalist bir gelişim teorisi üzerine bina edilen çalışma, eğitim bilimleri alanında Piaget tarafından kurulan bilimsel paradigmanın değişimine katkı sağlamıştır. Bu özelliğiyle kitap, doğrudan yazma alanıyla ilgili olmamakla birlikte yazma alanyazınını kuramsal açıdan önemli derecede etkilemiştir.

\section{Atıf Yapılan Dergilerin Ağ Analizi}

"Bilimsel iletişimde dergilerin özel bir yeri bulunmaktadır. Çeşitli bilim dallarında en güncel bilgileri içermeleri nedeniyle dergiler, kütüphane koleksiyonlarının en önemli kaynakları arasında yer almaktadır" (Küçük, Al ve Olcay, 2008: 309). Bilimsel iletişimin lokomotifi olan dergiler, çoğunlukla hakem denetimli olması yönüyle bilimsel çalışmaları nitelikli kılmanın önemli bir aracıdır. Bununla beraber dergilerin alana yön verme işlevi de bulunmaktadır. Şöyle ki araştırmacılar, çalışmalarını hazırlarken öncelikle alan dergilerinde yayımlanmış bilimsel yayınlara başvururlar. Bu nedenle bir alanda sıklıkla başvurulan dergilerin belirlenmesi, alan araştırmacılarının alandaki başat dergileri tanımalarına ve çalışmalarını dergi politikalarına göre yapılandırmasına olanak sağlar. Bu yanıyla belirlenen dergileri alan uzmanlarına yönelik okumaları ve izlemeleri gereken çekirdek dergi listesi olarak değerlendirmek mümkündür. Çalışmada WoS'ta listelenen yazma becerisi ile ilgili makalelerin kaynakçalarında eş atıf yapılan dergileri belirlemek için dergi ortak atıf analizi gerçekleştirilmiştir 
(Şekil 3). Ağ haritası, toplam 51,513 dergi atıfından, en az "50" defa atıf alan 390 dergi ile oluşturulmuştur.

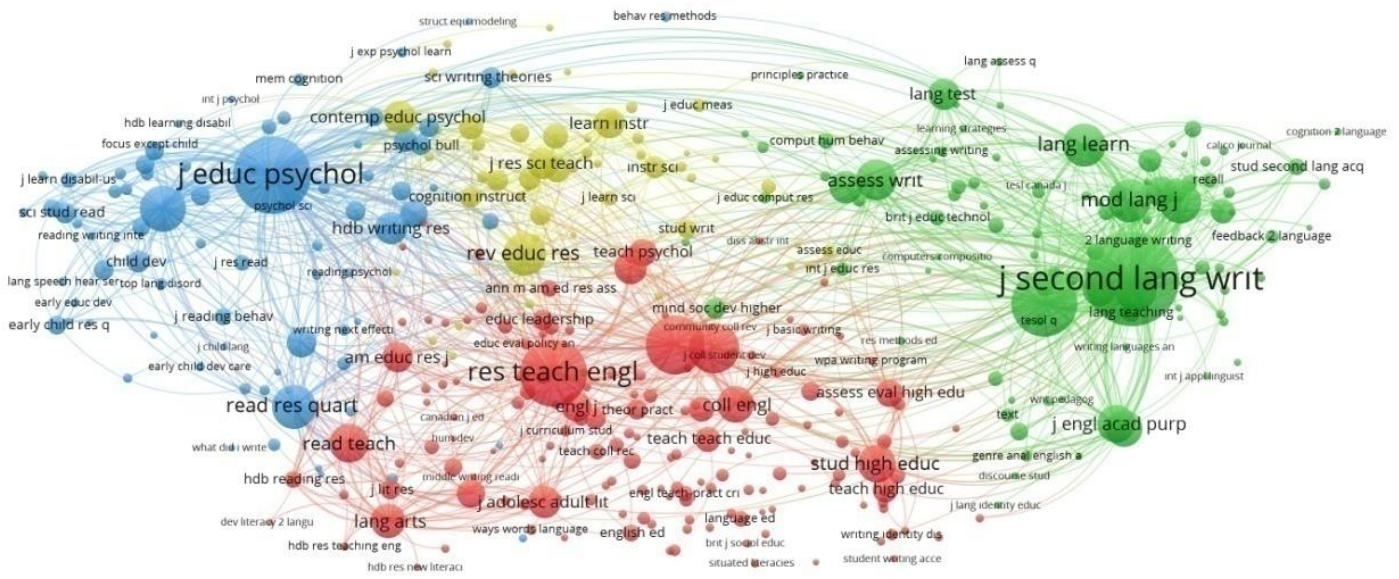

Şekil 3. Dergi ortak atıf ağ haritası

WoS'ta listelenen yazma becerisine ilişkin makalelerde en sık atıf yapılan dergilerle ilgili ă̆ haritasında 4 küme dikkat çekmektedir (Şekil 3). Kırmızı küme TD=157, yeşil küme $T D=100$, mavi küme $T D=78$, sarı küme ise $T D=18$ düğüme sahiptir. Buna göre en yoğun küme kırmızı, en gevşek küme ise sarı renkli kümelerdir.

Kırmızı kümede en güçlü düğüm Research in the Teaching of English dergisine aittir (TBG=55,621, Bağlantılar=2086). Derginin h-indeksi 47, etki faktörü ise 1.675'tir. Etki faktörü sıralaması bakımından dergi, eğitim ve eğitimsel araştırmalar kategorisindeki 243 dergi arasında 105. sıradadır. Dergi, 2018 JCR verilerine göre Q2 çeyreğinde yer almaktadır. Amerika Birleşik Devletleri adresli derginin konu alanı, İngilizce öğretimi özelinde dil eğitimi süreci, içeriği, bağlamı ve değerlendirmesidir. Bu kümede dikkat çeken bir diğer dergi ise Written Communication'dur (TBG=51,592, Bağlantılar=1654). Derginin h-indeksi 51, etki faktörü 1,219'dur. Dergi WoS, konu kategorilerine göre Communication kategorisinde bulunmaktadır. Etki faktörü sıralamasına göre dergi, iletişim kategorisindeki 88 dergi arasında 54. sıradadır. Dergi, 2018 JCR verilerine göre Q3 çeyreğinde yer almaktadır. Dergi, doğrudan yazııı iletişim ile ilgili olduğu için alanyazın açısından önemlidir. Diğer yandan dergi yazmanın tarih, antropoloji, eğitim, dilbilim, psikoloji gibi farklı disiplinlerle ilişkisine dayalı çalışmalara yer vermesi yönüyle alanyazında önemli bir bilimsel iletişim kanalıdır.

Yeşil kümede en yoğun bağlantı ağına sahip dergi, Journal of Second Language Writing'tir (TBG=125,446, Bağlantılar=3666). Dergi, Birleşik Krallık adresli olup h-indeksi 54, etki faktörü ise 4,200'dür. Dergi WoS konu kategorilerine göre Linguistics kategorisinde yer almaktadır. Etki faktörü sıralamasına göre, kendi kategorisindeki 184 dergi arasında 2. sıradadır. Dergi, 2018 JCR verilerine göre Q1 çeyreğinde yer almaktadır. Bu dergi, ikinci dilde yazma konusunu odağına almıştır. Buna göre ikinci dilde yazma süreci, ikinci dilde yazma öğretimini planlanma ve değerlendirme gibi konu alanları derginin odak ve kapsamını oluşturmaktadır. Yeşil kümede dikkat çeken bir diğer dergi ise TESOL Quarterly'dir (TBG=66,086, Bağlantılar=2026). TESOL Quarterly, ABD adresli olup h-indeksi 105, etki faktörü 2.718'dir. Dergi WoS konu kategorilerine göre disiplinler arası bir kaynaktır. Hem eğitim ve eğitim araştırmaları hem de dilbilim kategorisinde yer alan dergide çoğunlukla İngilizce öğretimi ile 
ilgili çalışmalar yayımlanmaktadır. 2018 JCR verilerine göre her iki konu kategorisinde de Q1 çeyreğinde yer almaktadır.

Mavi kümede düğüm yoğunluğu en yüksek dergi Journal of Educational Psychology'dir. (TBG=104,316, Bağlantılar=2630). Amerikan Psikoloji Derneği (APA) tarafından yayımlanan derginin, h-indeksi 210, etki faktörü 5.178'dir. Dergi WoS konu kategorilerine göre Psychology, Educational kategorisinde bulunmaktadır. Journal of Educational Psychology dergisi, kendi kategorisindeki 59 dergi arasında 3. sırada yer almaktadır. Dergi, Q1 çeyreklik dilimindedir. Bu dergide öncelikli olarak eğitim araştırmaları yayımlanmaktadır. Bununla birlikte eğitim psikolojisi konu alanından çalışmalara da yer verilmektedir. Derginin yazma alanında çalışma yapan araştırmacıların ilgisini çekiyor olmasının nedeni, aynı zamanda dil öğretimi odaklı araştırmaları da yayınlamasıdır. Bir başka veriye göre bu dergi yazma alanyazınında en çok atıf alan süreli kaynak niteliğine sahiptir. Bu kümede dikkat çeken bir diğer dergi Reading and Writing'dir (TBG=48,605, Bağlantılar=1114). 1990 yılından bu yana WoS'ta dizinlenen dergi Hollanda adresli olup h-indeksi 67, etki faktörü 1.942'dir. Reading and Writing okuma ve yazma becerileri ile dilbilim, bilişsel psikoloji, nöropsikoloji gibi farklı disiplinlerin ilişkisini ele alan çalışmalar yayımlamaktadır.

Sarı kümede en yüksek düğüm yoğunluğu Review of Educational Research adlı dergiye aittir (TBG=36,923, Bağlantılar=1013). ABD adresli olan derginin h-indeksi 171, etki faktörü 8.985'tir. Review of Educational Research WoS eğitim ve eğitimsel araştırmalar kategorisinde bulunmaktadır. Dergi eğitim ve eğitimsel araştırmalar kategorisinde 243 dergi arasında 1. sıradadır. Dergi, 2018 JCR verilerine göre Q1 çeyreğinde yer almaktadır. Bu göstergeler derginin eğitimbilim alanyazınında temel bilim iletişim kanalı olduğunu ortaya koymaktadır. Eğitim araştırmalarına yer veren dergi; psikoloji, tarih, edebiyat, siyaset bilimi, sosyoloji gibi farklı alanlardan çalışmaları eğitime odaklı olması koşuluyla yayımlamaktadır.

Atıf Yapılan Yazarların Ağ Analizi

WoS'ta dizinlenen yazma becerisine ilişkin makalelerin referans listelerinde yoğun biçimde atıf yapılan yazarları belirlemek için ortak atıf analizi yapılmıştır. Bu analiz çalışmaların kaynakça bölümlerindeki atıf yapılan yazar adlarına dayalı olarak gerçekleştirilmiştir. VOSviewer analitik aracı ile yapılan analizde makalelerde toplam 60.336 yazara atıf yapıldığı anlaşılmış, bu yazarlardan en az "45" kez atıf alan 438 yazarla oluşturulan ağ haritası aşağıda sunulmuştur (Şekil 4).

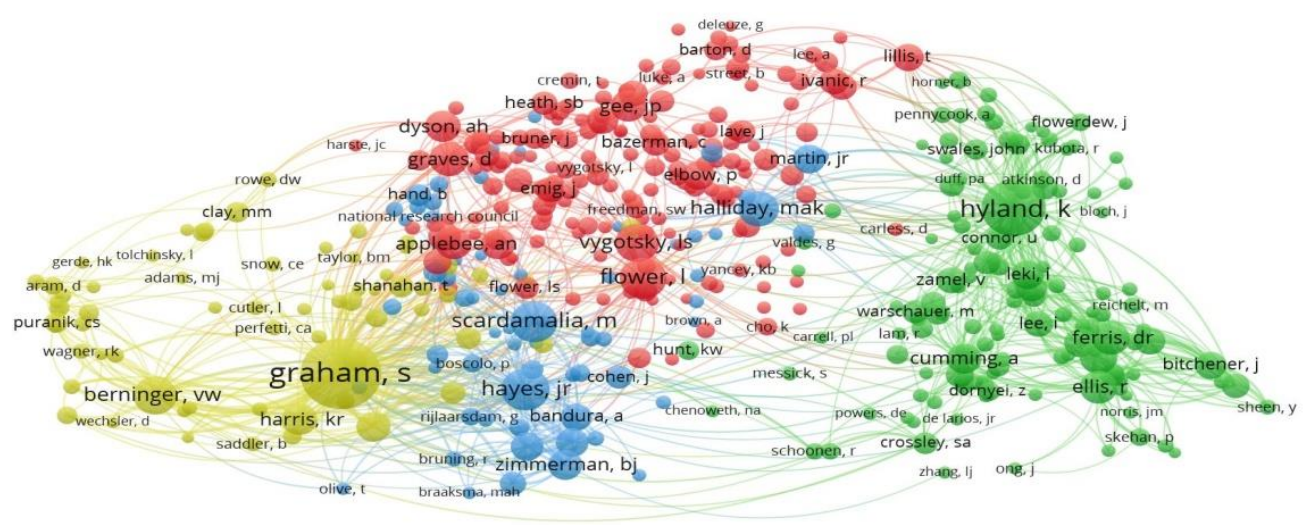

is vosviewer

Şekil 4. Yazar ortak atıf ağ haritası

Yazma alanyazınında sıkça atıf alan yazarların ağ haritasına bakıldığında 4 küme dikkat çekmektedir. Düğüm yoğunluğu en yüksek olan küme, kırmızı kümedir (TD=172). Bu kümeden sonra sırasıyla yeşil $(T D=135)$, mavi $(T D=66)$ ve sarı küme $(T D=65)$ gelmektedir. Kırmızı kümede en sık 
düğüm yoğunluğuna sahip yazar, Linda Flower'dır (TBG=13,813, Bağlantılar=547). Yazma becerisi ile ilgili kuram bilgisini ele alan önemli çalışmalara imza atan Flower, Carnegie Mellon Üniversitesi İngilizce Bölümünde bilimsel çalışmalarına devam etmektedir. Flower'ı, Rus psikolog Lev S. Vygotsky'i ( $T B G=10,482$, Bağlantılar=476) takip etmektedir.

Yeşil kümede dikkat çeken ilk yazar, Ken Hyland'dır (TBG=23,353, Bağlantılar=992). Hyland, East Anglia Üniversitesinde eğitimde uygulamalı dilbilim çalışmaları yürütmektedir. Google Akademik (GS) verilerine göre Hyland'ın h-indeksi 79 olup toplam 44,476 atıfı bulunmaktadır. Araştırmacının bilimsel çalışma alanları uygulamalı dilbilim, dil eğitimi, yazma ve akademik söylemdir. Bu kümede Hyland'ı, Dana Ferris izlemektedir (TBG=9669, Bağlantılar=360). Ferris'in h-indeksi 38 olup toplam 16,895 atıfı bulunmaktadır. Kaliforniya Üniversitesi Yazma Programı Direktörü olan Ferris'in; yaratıcı yazma, ikinci dil olarak İngilizce öğretimi, dilbilim gibi alanlarda çalışmaları olduğu bilinmektedir.

Mavi kümede en yüksek düğüm yoğunluğu John R. Hayes'e aittir (TBG=17,843, Bağlantılar=566). Carnegie Mellon Üniversitesi Psikoloji Bölümünde bilimsel çalışmalarına devam eden Hayes'in Linda Flower ile yayımladıkları "A Cognitive Process Theory of Writing" başlıklı makaleye Google Akademik verilerine göre 5555 atıf yapılmıştır. Hayes'in gerek yazma alanıyla gerekse bilişsel psikoloji ile ilgili çalışmaları bilimsel çevrelerde ilgi görmeye devam etmektedir. Bu kümede Hayes'ten sonra Marlene Scardamalia'yı anmak gerekir. Akademik çalışmalarını Toronto Üniversitesinde sürdüren araştırmacının h-indeksi 69 olup toplam 39,292 atıfı bulunmaktadır. Araştırmacının Carl Bereiter ile 1987 yılında yayımladığı The Psychology of Written Composition başıkı kitap alanyazında bilimsel iletişimin gelişimine katkı sağlamıştır. Çalışma yazıı metinleri oluşturma sürecinde hedef belirleme, planlama, bellek tarama, problem çözme, değerlendirme ve teşhis gibi zihinsel etkinliklere odaklanan temel çalışmalardan olması yönüyle önemlidir.

Sarı kümede ve yazma alanyazınında en güçlü düğüm yapısına sahip yazar Steve Graham'dır (TBG=45,397, Bağlantılar=1613). Arizona Devlet Üniversitesine bağıl olarak çalışmalarını yürüten Graham'ın Google Akademik (GS) verilerine göre h-indeksi 120 olup toplam 44,421 atıfı bulunmaktadır. Yazma becerisinin öğretimi ve gelişimi ile ilgili hem uygulamalı hem de kuramsal birçok çalışması bulunan Graham, alanyazında uluslararası etki ve prestij boyutuyla önde gelen araştırmacılardan biridir. Bu kümede Graham'dan sonra dikkat çeken yazarlar Virginia W. Berninger (TBG=15,671, Bağlantılar=479) ve Karen R. Harris'dir (TBG=9705, Bağlantılar=312). Graham'ın yazma alanyazında Berninger ve Harris ile birlikte çalışmaları bulunmaktadır.

\section{Tartışma, Sonuç ve Öneriler}

Yazma, bilişsel ve psikomotor becerilerin işe koşulduğu bir anlatma becerisi olup, Türkiye'de olduğu gibi dünya genelinde de bilim çevreleri tarafından ilgi gören bir çalışma alanıdır. Bibliyometri, bilimsel alanların yapısını değerlendirmek, analiz etmek ve görselleştirmek için kullanılan güncel bir tekniktir (Koskinen ve diğerleri, 2008). Başlangıçta bibliyometri, temel olarak coğrafi, kurumsal ve konu alanlarını kullanarak bilimsel yapılara genel bir bakış sunmuştur. Bununla birlikte, bibliyometrik araçların ya da yazııımların geliştirilmesi, o zamandan beri, alanyazının büyümesini ve etkisini çeşitli yollarla analiz etmeyi ve yorumlamayı mümkün kılmaktadır (Ellegaard ve Wallin, 2015). Bu yönüyle alan araştırmacılarının alanyazın hakkında sahip olduğu bilgi ve görüşleri kanıta dayalı biçimde temellendirmelerine olanak sunmaktadır. Bu çalışmada 1975-2019 döneminde yazma becerisiyle ilgili WoS veri tabanında listelenen makaleleri bibliyometri yöntemiyle incelemek amaçlanmıştır. Bu kapsamda alanyazının büyüklüğü, dayandığı kuramsal altyapı ve alanda ortaya çıkan güncel konu başıkları belirlenmiştir. Böylece WoS atıf dizini üzerinden alanyazındaki çeşitli eğilimler saptanmış ve bir durum raporu ortaya konulmuştur.

Alanyazına yön veren makaleler, çalışma disiplinini şekillendiren temel metinlerdendir. Bu yanıyla alan araştırmacıları açısından kılavuz niteliği taşımaktadır. En sık atıf alan ilk 20 makale, 7 farklı ülke adresli 47 yazar tarafından üretilmiştir. Makalelerin tamamı İngilizce olarak yayımlanmıştır. Hallinger ve Kovačević'in belirttiği gibi (2019) bu makalelerin [çekirdek makale] okunması, mevcut ve gelecekteki alan araştırmacı kuşaklarını, bilgi birikiminin dolaşım sürecine duyarı hâle getirecek ve alanla ilgili çalışmalarda süregelen zorluklara ilişkin yeni bilgiler sağlayacaktır. Alana yol gösteren bu yayınların büyük çoğunluğu iki ve daha fazla yazar tarafından yayımlanmıştır. Bu veri sosyal ve beşerî 
bilimlerde görülen tek yazarlı çalışma eğiliminden farklı bir durum ortaya koymaktadır. Daha açıklayıcı bir anlatımla çalışma disiplininde bilimsel iş birliğinin yoğun olduğunu belirtmek mümkündür.

WoS atıf dizininde listelenen makalelerin yazar adreslerine bakıldığında, araştırmacıların çoğunlukla $A B D$, Kanada ve İngiltere adresli olduğu görülmektedir. Başka bir deyişle Avrupa-Atlantik ekolüne bağlı kurumlardaki araştırmacılar alanın entelektüel yapısının oluşumunda etkin rol oynamaktadır. Bu bulgu, okuma alanyazınına ilişkin olarak Karagöz ve Şeref'in (2019a) dile getirdiği Anglo-Sakson baskınlığı ile benzer bir sonuca işaret etmektedir. Bu nedenle, belirtilen bilim odaklarındaki araştırmacıların izlenmesi, yayınlarının analiz edilmesi Türkçe eğitimi akademik alanındaki araştırmacılar açısından önemli görülmektedir. Böylece Türkçe eğitimi çalışmalarının kapsam açısından zenginleşmesi, ulusal görünümünü aşarak uluslararası bilgi ağı ile etkileşime girmesi mümkün olabilir.

Yazma araştırmalarının konu alanı eğilimlerinin belirlenmesi Türkçe eğitimi alanında yapılacak çalışmaların planlanması açısından önemlidir. Bu amaçla yapılan anahtar kelime ağ analizine göre yazma alanyazınında son yıllarda akademik yazma konu alanının önem kazandığı görülmektedir. Buna karşılık Türkçe eğitimi akademik alanına bakıldığında akademik yazma çalışmalarının sınırlı sayıda olduğu dikkat çekmektedir (Bayat, 2014; Deniz ve Karagöl, 2017a; Deniz ve Karagöl, 2017b; Deniz ve Karagöl, 2018; Kan ve Gedik, 2016; Kan, 2017; Seyedı, 2019; Tok ve Potur, 2015; Tok, 2013). Alanda gerçekleştirilen lisansüstü tez çalışmalarında da benzer bir durum söz konusudur. YÖK Ulusal Tez merkezi verilerine göre Türkçe eğitimi ile Türk dili ve edebiyatı eğitimi akademik alanlarında akademik yazmaya yönelik toplam 4 doktora tezi kayıtlı bulunmaktadır (Yükseköğretim Kurulu [YÖK], 2019). Eldeki veriler, Türkçe eğitimi akademik alanında akademik yazma konu alanına ilişkin niceliksel bir eksikliğe işaret etmektedir. Bu durum yazma araştırmalarında güncel konu alanı olarak akademik yazmanın ön planda olması ile birlikte değerlendirildiğinde, Türkçe eğitimi alanında akademik yazmanın her düzeyde uygulama, betimleme, planlama yönleriyle daha çok çalışılması gerektiği sonucunu ortaya koymaktadır.

Yazma alanı ile ilgili WoS'ta listelenen araştırmalarda çoğunlukla Journal of Second Language Writing, TESOL Quarterly, Journal of Educational Psychology, Review of Educational Research gibi Q1 çeyreğinde bulunan dergilere atıf yapıldığı anlaşılmıştır. Etki değeri yüksek dergiler ilk \%25'lik dilimde, etki değeri ortalama düzeydeki dergiler ikinci \%25'lik dilimde, etki değeri ortalamaya yakın dergiler üçüncü \%25'lik dilimde ve etki değeri sıfır veya çok düşük dergiler son \%25'lik dilimde yer al[ır]. (University Ranking by Academic Performance [URAP], 2018). Buna göre WoS'ta dizinlenen dergiler Q1, Q2, Q3 ve Q4 biçiminde gruplara ayrılır. Etki değeri en yüksek dergiler Q1 dergi grubunda bulunmaktadır. Bu veri, anılan dergilerin WoS etki faktörü bağlamında ön sıralarda yer aldığını göstermektedir. İncelenen makalelerde bu dergilere atıf yapılmış olması makalelerin bilimsel niteliğini artıran bir gösterge olarak değerlendirilebilir. Bu bilgiden hareketle Türkçe eğitimi akademik alanında gelecekteki yazma araştırmalarında bu dergilerde yayımlanan çalışmaların gözden geçirilmesi önemli görülmektedir. Böylelikle bu araştırmalarla birlikte hem Türkçe eğitimi akademik alanındaki çalışmalar daha üst bir düzeye ulaşabilir hem de alan araştırmacılarının uluslararası alanyazından daha etkin biçimde yararlanmaları sağlanabilir.

Incelenen makalelerde; Carl Bereiter [Google Akademik Atıfı $(G A A)=43,663$; h-indeksi=75), Dana Ferris (GAA=16,895, h-indeksi=38), Etienne Wenger ( $G A A=176,240$, h-indeksi=59), Ken Hyland (GAA=44,621, h-indeksi=79), Marlene Scardamalia (GAA=39,292, h-indeksi=69), Steve Graham $(G A A=44,421$, h-indeksi=120) gibi çekirdek araştırmacıların eserlerine sıklıkla başvurulduğu görülmüştür. Söz konusu bilim adamlarının yazma alanı ile ilgili alanı yönlendiren önemli çalışmaları bulunmaktadır. Türkçe eğitimi akademik alanında yapılacak bilimsel araştırmalarda, anılan araştırmacıların yayımladıkları çalışmaların dikkatle izlenmesi, alanın bilimsel gelişiminin niteliği ve uluslararası kimlik kazanması bakımından son derece önemlidir. Çünkü bu yazarlar yazma alanyazınını entelektüel katkı yönünden önemli derecede etkilemiştir. Özellikle lisansüstü eğitim döneminde ders aşamasında olan genç araştırmacılara, belirtilen yazarların kitap, makale vb. bilimsel yayınları okuma listesi olarak verilebilir. İngilizce yeterliği olan araştırmacılar kanonik karakter kazanmış çekirdek yayınları tercüme etmeye özendirilebilir. Bu yayınların Türkçeye kazandırılması alanyazında bilim iletişimine katkıda bulunabilir. Bilimsel otoritelerin (kitap, makale, araştırmacı vb.) rolünü irdeleyerek 
alanyazındaki dinamikleri keşfetmelerine olanak verebilir. Böylece genç araştırmacıların alanyazının entelektüel temellerini kavramalarına ortam sağlanabilir. Aynı zamanda güncel eğilimleri izleyerek yeni araştırma konuları hakkında farkındalık kazanmalarının önü açılabilir. Bunun sonucunda Türkçe eğitimi bilim alanında yazma becerisi bağlamında üretilen tez ve makalelerin evrensel bilgi birikimi ile bütünleşmesi sağlanabilir.

Son zamanlarda farklı disiplinlerde bibliyometri çalışmalarında bir artış olduğu dikkat çekmektedir. Türkçe eğitimi akademik alanında ise az sayıda bibliyometri çalışması mevcuttur (Karagöz ve Koç Ardıç, 2019; Karagöz ve Şeref, 2019a; Şeref ve Karagöz, 2019a; Şeref ve Karagöz, 2019b). Bu çalışmanın yazma alanı ile ilgili WoS'ta listelenen makaleler üzerinden yürütüldüğü düşünüldüğünde bibliyometri kullanılarak dinleme, konuşma gibi temel dil becerilerine yönelik bibliyometrik çalışmalara gereksinim bulunmaktadır. Temel dil becerilerinin dışında Türkçe eğitimi akademik alanının alt alanlarını hedefleyen bibliyometrik araştırmalar da gerçekleştirilebilir.

Türkçe eğitimi alanında makale ve tezlere yönelik olarak içerik analizi ve meta-analizi çalışmaları yapıldığı bilinmektedir. Ancak bu çalışmalar uluslararası alanyazın ile kısmi bir bağlantı kurmaktadır. Ayrıca söz konusu araştırmaların çoğunlukla elle sayım prosedürüne bağlı kaldığı görülmektedir. Bununla birlikte analitik araçlarla gerçekleştirilen bilim haritalama uygulamaları kümeler arasındaki görünmeyen ilişkileri, bilimsel odakları ve alanın dinamik yapısını betimleme olanağı sunmaktadır. Bu nedenle gelecekte Türkçe eğitimi alanında makale ve tezler üzerinden çalışmalar yürütmeyi planlayan araştırmacılara bu tekniği kullanarak çalışma yapmaları önerilmektedir.

Bu çalışmanın iki temel sınırlılığı bulunmaktadır. Çalışmanın ilk sınırılığı, WoS veri tabanında eğitim ve eğitimsel araştırmalar kategorisinde dizinlenen makalelerin analizine dayanmasıdır. WoS, araştırmacılara alanyazın incelemesi ve atıf analizi için kapsamlı ve standardize edilmiş bir veri seti sunmaktadır. Ayrıca bilim çevrelerinde yüksek düzeyde bir saygınlığa sahiptir. Bu yönüyle WoS veri tabanı, eğitim ve eğitimsel araştırmalar kategorisinde yapılacak bibliyometrik çalışmalar için bu kategorinin bulunmadığı veri tabanlarına (örn. Scopus) kıyasla daha uygun bir seçenektir.

Çalışmanın ikinci sınırlılı̆ı Ulakbim TR Dizin, Scopus vb. diğer veri tabanlarında dizinlenen makaleleri, çalışma kapsamına dâhil etmemesidir. Dolayısıyla oluşturulan bibliyometrik haritalar alanyazın ile ilgili gerçeği bütünüyle yansıtmayabilir. Elde edilen bibliyometrik görselleştirmeler bu dikkatle okunmalıdır.

\section{Kaynaklar}

Akyol, H. (2011). Türkçe ilk okuma ve yazma öğretimi. Ankara: Pegem Akademi.

Al, U. (2012). Avrupa Birliği ülkeleri ve Türkiye'nin yayın ve atıf performansı. Bilig, 62, 1-20.

Arıcı, A. F. ve Ungan, S. (2008). İlköğretim ikinci kademe öğrencilerinin yazıı anlatım çalışmalarının bazı yönlerden değerlendirilmesi. Dumlupınar Üniversitesi Sosyal Bilimler Dergisi, 20, 317328.

Bangert-Drowns, R. L., Hurley, M. M., ve Wilkinson, B. (2004). The effects of school-based writing-tolearn interventions on academic achievement: A meta-analysis. Review of Educational Research, 74(1), 29-58.

Bayat, N. (2014). Öğretmen adaylarının eleştirel düşünme düzeyleri ile akademik yazma başarıları arasındaki ilişki. Eğitim ve Bilim, 39(173), 155-168.

Berninger, V., Yates, C., Cartwright, A., Rutberg, J., Remy, E., ve Abbott, R. (1992). Lower-level developmental skills in beginning writing. Reading and Writing, 4(3), 257-280.

Bialystok, E., Luk, G., ve Kwan, E. (2005). Bilingualism, biliteracy, and learning to read: Interactions among languages and writing systems. Scientific Studies of Reading, 9(1), 43-61.

Buzydlowski J.W., White H.D., ve Lin X. (2002) Term Co-occurrence Analysis as an Interface for Digital Libraries. In: Börner K., Chen C. (eds) Visual Interfaces to Digital Libraries. Lecture Notes in Computer Science, vol 2539. Springer, Berlin, Heidelberg.

Cambrosio, A., Limoges, C., Courtial, J. P., ve Laville, F. (1993). Historical scientometircs? Mapping over 70 years of biological safety research with co-word analysis. Scientometrics, 27(2), 119143. 
Canagarajah, S. (2011). Codemeshing in academic writing: Identifying teachable strategies of translanguaging. The Modern Language Journal, 95(3), 401-417.

Chen, C. (1999). Visualising semantic spaces and author co-citation networks in digital libraries. Information processing \& management, 35(3), 401-420.

Cheng, Y. S., Horwitz, E. K., ve Schallert, D. L. (1999). Language anxiety: Differentiating writing and speaking components. Language Learning, 49(3), 417-446.

Cho, K. ve Schunn, C. D. (2007). Scaffolded writing and rewriting in the discipline: A web-based reciprocal peer review system. Computers \& Education, 48(3), 409-426.

Cobo, M. J., López-Herrera, A. G., Herrera-Viedma, E., ve Herrera, F. (2011). Science mapping software tools: Review, analysis, and cooperative study among tools. Journal of the American Society for Information Science and Technology, 62(7), 1382-1402.

Coşkun E., Balcı A. ve Özçakmak H. (2013). Trends in writing education: An analysis of post graduate theses written in Turkey. Procedia-Socialand Behavioral Sciences, 93, 1526-1530.

Cumming, A. (1989). Writing expertise and second-language proficiency. Language Learning, 39(1), 81-135.

Deniz, K. ve Karagöl, E. (2017a). Akademik yazma açısından makale hakem değerlendirme formları. Electronic Turkish Studies, 12(34), 143-162.

Deniz, K. ve Karagöl, E. (2017b). Akademik yazma açısından tez yazım kılavuzları. Ana Dili Eğitimi Dergisi, 5(2), 287-312.

Deniz, K. ve Karagöl, E. (2018). Akademik yazma açısından dergi yazar rehberleri. Ana Dili Eğitimi Dergisi, 6(4), 1210-1225.

Elbir, B. ve Yıldız, H. (2012). İlköğretim yazma eğitimi üzerine yapılan lisansüstü çalışmalarının değerlendirilmesi. Akademik Bakış Dergisi, 30, 1-11.

Ellegaard, O. ve Wallin, J. A. (2015). The bibliometric analysis of scholarly production: How great is the impact?. Scientometrics, 105(3), 1809-1831.

Englert, C. S., Raphael, T. E., Anderson Helene M. Anthony, L. M., ve Stevens, D. D. (1991). Making strategies and self-talk visible: Writing instruction in regular and special education classrooms. American Educational Research Journal, 28(2), 337-372.

Epçaçan, C. (2013). Çoklu zeka kuramına dayalı öğretim uygulamalarının öğrencilerin okuduğunu anlama becerilerine etkisi. Turkish Studies, 8(1), 1335-1353.

Fahimnia, B., Sarkis, J. ve Davarzani, H. (2015). Green supply chain management: A review and bibliometric analysis. International Journal of Production Economics, 162, 101-114.

Fitzgerald, J. ve Shanahan, T. (2000). Reading and writing relations and their development. Educational Psychologist, 35(1), 39-50.

Garfield, E. (1990). Keywords plus-ISIS breakthrough retrieval method. 1. Expanding your searching power on current-contents on diskette. Current Contents, 32, 5-9.

Göçer, A. (2010). Writing education in Turkish teaching. The Journal of International Social Research, 3(12), 178-195.

Göksu, E. (2016). İlköğretim düzeyi yazma becerileri ile ilgili makalelerin ve lisansüstü tezlerin çok yönlü incelenmesi. Yayımlanmamış Yüksek Lisans Tezi, Gazi Üniversitesi Eğitim Bilimleri Enstitüsü, Ankara.

Graham, S. ve R. Harris, K. (2000). The role of self-regulation and transcription skills in writing and writing development. Educational Psychologist, 35(1), 3-12.

Güneş, F. (2014). Türkçe öğretimi yaklaşım ve modeller. Ankara: Pegem Akademi.

Hallinger, P. ve Kovačević, J. (2019). A bibliometric review of research on educational administration: Science mapping the literature, 1960 to 2018. Review of Educational Research, 89(3), 335369.

Harris, K. R., Graham, S. ve Mason, L. H. (2006). Improving the writing, knowledge, and motivation of struggling young writers: Effects of self-regulated strategy development with and without peer support. American Educational Research Journal, 43(2), 295-340.

Kan, M. O. (2017). Türkiye'de akademik yazma alanında yapılan lisansüstü tezler. Insan ve Toplum Bilimleri Araştırmaları Dergisi, 6(2), 1037-1048. 
Kan, M. O. ve Gedik, F. N. (2016). Türkçe eğitimi alanında yüksek lisans tezi tamamlayanların akademik yazma ve tez oluşturma sürecine ilişkin görüşleri. Yükseköğretim ve Bilim Dergisi, 6(3), 404-410.

Kaptan, S. (1998). Bilimsel araştırma ve istatistik teknikleri (11. Baskı). Ankara: Tek Işık Web Ofset.

Karagöl, E. (2018). Akademik yazma açııından lisansüstü tezler. Yayımlanmamış Doktora Tezi, Gazi Üniversitesi Eğitim Bilimleri Enstitüsü, Ankara.

Karagöz, B. ve Koç Ardıç, i. (2019). Ana Dili Eğitimi Dergisinde yayımlanan makalelerin bibliyometrik analizi. Ana Dili Eğitimi Dergisi, 7(2), 419-435.

Karagöz, B. ve Şeref, i. (2019a). Okuma alanındaki araştırmaların bibliyometrik özellikler açısından incelenmesi. Ana Dili Eğitimi Dergisi, 7(3), 781-799.

Karagöz, B. ve Şeref, ì. (2019b). Değerler Eğitimi Dergisi'nin bibliyometrik profili (2009-2018). Değerler Eğitimi Dergisi, 17(37), 219-246.

Karatay, H. (2011). 4+1 planlı yazma ve değerlendirme modelinin öğretmen adaylarının yazılı anlatım tutumlarını ve yazma becerilerini geliştirmeye etkisi. Turkish Studies, 6(3), 1029-1047.

Kelly, G. J. ve Takao, A. (2002). Epistemic levels in argument: An analysis of university oceanography students' use of evidence in writing. Science Education, 86(3), 314-342.

Keys, C. W., Hand, B., Prain, V., ve Collins, S. (1999). Using the science writing heuristic as a tool for learning from laboratory investigations in secondary science. Journal of Research in Science Teaching, 36(10), 1065-1084.

Koskinen, J. ve ark. (2008). How to use bibliometric methods in evaluation of scientific research? An example from finnish schizophrenia research. Nordic Journal of Psychiatry, 62(2), 136-143.

Kovačević, J. ve Hallinger, P. (2019). Leading school change and improvement: A bibliometric analysis of the knowledge base (1960-2017). Journal of Educational Administration. Erişim adresi: https://doi.org/10.1108/JEA-02-2019-0018.

Küçük, M. E., Al, U. ve Olcay, N. E. (2008). Türkiye'de bilimsel elektronik dergiler. Türk Kütüphaneciliği, 22(3), 308-319.

Lam, W. S. E. (2000). L2 literacy and the design of the self: A case study of a teenager writing on the Internet. TESOL Quarterly, 34(3), 457-482.

Lea, M. R. ve Street, B. V. (1998). Student writing in higher education: An academic literacies approach. Studies in Higher Education, 23(2), 157-172.

McCutchen, D. (2000). Knowledge, processing, and working memory: Implications for a theory of writing. Educational Psychologist, 35(1), 13-23.

MEB. (2018). Türkçe dersi öğretim programı ve kılavuzu (1-8. Sınıflar). Ankara: Millî Eğitim Bakanlığı.

Onan, B. (2006). Ses olgusunun denetlenebilirliği bağlamında dil becerilerinin geliştirilmesinde etkili olduğu düşünülen fonolojik yönlendiriciler. Türklük Bilimi Araştırmaları Dergisi, 20, 141-163.

Özdemir, N. H. ve Erdem, i. (2011). Türkçe öğretmeni adaylarının yazma alışkanlıklarının bazı değişkenler açısından incelenmesi. Uşak Üniversitesi Sosyal Bilimler Dergisi, 4(2), 101-125.

Rao, Z. (2007). Training in brainstorming and developing writing skills. ELT Journal, 61(2), 100-106.

Robb, T., Ross, S. ve Shortreed, I. (1986). Salience of feedback on error and its effect on EFL writing quality. TESOL Quarterly, 20(1), 83-96.

Seyedı, G. (2019). Yabancı dil olarak Türkçe öğretiminde akademik yazma öğretimi. Yayımlanmamış Doktora Tezi, Hacettepe Üniversitesi Türkiyat Araştırmaları Enstitüsü, Ankara.

Silva, T. (1993). Toward an understanding of the distinct nature of L2 writing: The ESL research and its implications. TESOL Quarterly, 27(4), 657-677.

Şeref, i. ve Karagöz, B. (2019a). A bibliometric profile of literature of Turkish language educationteaching: A case study of 9th International Language Education-Teaching Conference. European Journal of Alternative Education Studies, 4(1), 106-124.

Şeref, i. ve Karagöz, B. (2019b). Türkçe eğitimi akademik alanına ilişkin bir değerlendirme: Web of Science veri tabanına dayalı bibliyometrik inceleme. Dil Eğitimi ve Araştırmaları Dergisi, 5(2), 213-231.

Tok, M. (2013). Türkçenin yabancı dil olarak öğretiminde akademik yazma ihtiyacı. Mustafa Kemal Üniversitesi Sosyal Bilimler Enstitüsü Dergisi, 10(23), 1-25. 
Tok, M. ve Potur, Ö. (2015). Yazma eğitimi alanında yapılan akademik çalışmaların eğilimleri (20102014 Yılları). Ana Dili Eğitimi Dergisi, 3(4), 1-25.

Tsay, M. Y., Xu, H. ve Wu, C. W. (2003). Journal co-citation analysis of semiconductor literature. Scientometrics, 57(1), 7-25.

Turan, L., Sevim, O. ve Tunagür, M. (2018). Türkçe eğitimi alanında hazırlanan doktora tez özetlerine yönelik bir içerik analizi. Uluslararası Türk Eğitim Bilimleri Dergisi, 6(11), 29-44.

URAP Araştırma Laboratuvarı (2018). http://tr.urapcenter.org/2018/2017-2018-URAP-TurkiyeSiralamasi-Raporu.pdf Erişim tarihi: 28.10.2019.

Uyar, Y. (2016). Yazma becerisini geliştirmeye yönelik araştırmalar: Son çeyrek asrın değerlendirilmesi. Turkish Studies, 11, 2273-2294.

Ülper, H. ve Uzun, L. (2009). Bilişsel süreç modeline göre hazırlanan yazma öğretimi izlencesinin öğrenci başarısına etkisi. Illköğretim Online, 8(3), 651-665.

Van Eck, N. J. ve Waltman, L. (2017). Citation-based clustering of publications using CitNetExplorer and VOSviewer. Scientometrics, 111(2), 1053-1070.

Van Eck, N. J., Waltman, L., Dekker, R., ve Van den Berg, J. (2010). A comparison of two techniques for bibliometric mapping: Multidimensional scaling and VOS. Journal of the American Society for Information Science and Technology, 61(12), 2405-2416.

Yazıcı, N. (2006). Türk edebiyatında otobiyografi. Türkbilig/Türkoloji Araştırmaları Dergisi, 7(11), 189217.

YÖK Ulusal Tez Veritabanı (2019). https://tez.yok.gov.tr/UlusalTezMerkezi/tezSorguSonucYeni.jsp Erişim tarihi: 10.09.2019.

Zamel, V. (1985). Responding to student writing. TESOL Quarterly, 19(1), 79-101.

Zimmerman, B. J. ve Bandura, A. (1994). Impact of self-regulatory influences on writing course attainment. American Educational Research Journal, 31(4), 845-862.

http://lert.co.nz/map/.

\section{Extended Abstract}

Introduction

Writing is a multidimensional skill that includes "the environment of activity, the author's long-term memory and the writing process" (Ülper and Uzun, 2009: 652). It is an important linguistic skill. It stimulates thinking, encourages students to develop and organize their ideas, and fosters their ability to summarize, analyze and criticize (Rao, 2007). By activating the processes of hearing and thinking, it contributes to the development of an individual's relationship with the environment. In this sense, writing has an important function in the development of mental skills such as thinking, understanding, sorting, classifying, questioning, establishing relationships, analyzing, synthesizing and evaluating" (MEB, 2018: 10). Writing also enables intergenerational interaction and makes social memory permanent. In this respect, it prepares the environment for the transfer of historical and cultural heritage to future generations.

The purpose of this study is to examine the articles listed in the WoS core collection on the writing skill to identify current trends and thus present a new research framework to the academic field of Turkish education. For this purpose, the study sought to answer the question "What are the bibliometric views of the articles related to writing skills listed in WoS?"

\section{Method}

This descriptive study is qualitative by design. The descriptive method is used to answer questions such as "What is the situation in the research?, Where are we?, What do we want to do?, Where, which direction should we go?, How do we go there?", based on the data in the current timeframe (Kaptan, 1995: 59).

In the study, the Web of Science (WoS), database was used. The database provides researchers with a comprehensive and standardized data set for literature review and citation analysis. In order to reach the refereed articles on the writing skill, online inquiry was made on 05.08.2019 in the WoS database. 
In this context, the search query was conducted in the categories of education and educational research in the WoS core collection for the period of 1975-2019. The data set was limited to the document type article and a total of 5,779 articles were reached.

In the research, bibliometrics was used as the data analysis method and the bibliometric analysis was performed in seven categories: (1) Number of articles and citations, (2) Countries / regions, (3) Articles in the literature, (4) Keyword analysis, (5) Document (Source) joint citation network analysis, (6) Journal joint citation network analysis and (7) Author joint citation network analysis.

Bibliometric software tools are important in visualizing bibliometric data. Version 1.6 .9 of the VOSviewer analytical tool was used to map the data (https://www.vosviewer.com/). VOSviewer provides a graphical user interface that provides easy access to VOS mapping technique.

\section{Result and Discussion}

After the size of the literature, the infrastructure it is based on and the current topics in the field had been determined, various trends for the literature were identified through the WoS citation index and a status report was presented.

The articles that are considered basic texts shape the field. In this respect, they provide a guide for field researchers. The first 20 most frequently cited articles were written by 47 authors from 7 different countries. All articles were published in English. As Hallinger and Kovačević pointed out (2019), the reading of these articles [core articles] will make the current and future field researcher susceptible to the circulating process of knowledge and provide new insights into the ongoing challenges in field-related studies.

Looking at the author addresses of the articles listed in the WoS citation index, it is seen that the researchers are mostly from USA, Canada and England. In other words, researchers in EuroAtlantic institutions play an active role in the formation of the intellectual structure of the field.

Determining the subject area trends of the writing research listed in the WoS is important for planning studies in the academic field of Turkish education. The keyword network analysis showed that the subject area of academic writing has been dwelled on in recent years and few studies on academic writing in Turkish education are available (Bayat, 2014; Deniz and Karagöl, 2017; Deniz and Karagöl, 2018; Kan and Gedik, 2016; Kan, 2017; Karagöl and Deniz, 2017; Tok and Potur, 2015; Tok, 2013). 